\title{
Constraints on the thermal and tectonic evolution of Greymouth coalfield
}

\author{
PETER J. J. KAMP \\ IAN W.S. WHITEHOUSE \\ Department of Earth Sciences \\ The University of Waikato \\ Private Bag 3105 \\ Hamilton, New Zealand

\section{JANE NEWMAN} \\ Newman Energy Research \\ 2 Rose Street \\ Christchurch, New Zealand
}

\begin{abstract}
The southern end of the Paparoa Range in Westland, South Island, New Zealand, comprises an asymmetrical, southward plunging, faulted (Brunner-Mt Davy) anticline, the eastern limb of which is common with the western limb of an asymmetrical (Grey Valley) syncline forming a Neogene foreland basin (Grey Valley Trough). The faulted anticline is a classic inversion structure: compression during the Neogene, associated with the development of the modern Australia-Pacific plate boundary, caused a pre-existing normal fault zone, about which a late Cretaceous-Oligocene extensional half graben had formed (Paparoa Trough), to change its sense of displacement. The resulting basement loading formed the foreland basin, containing up to $3 \mathrm{~km}$ of mainly marine sedimentary section.

Fission track results for apatite concentrates from 41 shallow drillhole and outcrop samples from the Greymouth Coalfield part of the Brunner-Mt Davy Anticline are reported and interpreted, to better establish the timing and amount of inversion, and hence the mechanism of inversion. The fission track results integrated with modelling of vitrinite reflectance data, show that the maximum paleotemperatures experienced during burial of the Late Cretaceous and mid-Eocene coalbearing succession everywhere exceeded $85^{\circ} \mathrm{C}$, and reached a peak of $180^{\circ} \mathrm{C}$ along the axis of the former basin. Cooling from maximum temperatures occurred during three discrete phases: 20-15 Ma, 12-7 Ma, and c. $2 \mathrm{Ma}$ to the present. The amount of denudation has been variable across the inverted basin, decreasing westward from a maximum of $\mathrm{c}$. $2.5 \mathrm{~km}$ during the first deformation phase, c. $1.2 \mathrm{~km}$ during the second phase, and $1.4 \mathrm{~km}$ during the third phase. It appears that exhumation over the coalfield continued for about $2 \mathrm{~m}$.y. beyond the biostratigraphically determined time ranges of each of two synorogenic unconformities along the western limb of the Grey Valley Syncline. Stick-slip behaviour on the range front fault that localised the inversion is inferred. The tectonic evolution of the anticline-syncline
\end{abstract}

G98009

Received 27 April 1998; accepted 25 March 1999 pair at the southern end of the Paparoa Range, is therefore identical in style, and similar in timing, to the development of the Papahaua Range-Westport Trough across the Kongahu Fault Zone, in the vicinity of Buller Coalfield.

Keywords Greymouth Coalfield; inversion; foreland; fission track; vitrinite reflectance; thermochronology

\section{INTRODUCTION}

In the Westland-Buller region of South Island, New Zealand (Fig. 1), there have been major late Cenozoic changes in the sense of vertical movement on long-lived faults, which has led to the inversion of Late Cretaceous to mid Cenozoic extensional half-grabens, and the simultaneous formation of adjacent basins of foreland character. The best documented example of this structural inversion involves the southern end of the Paparoa Range, which incorporates the Greymouth Coalfield, and the adjacent Grey Valley Trough (Gage 1952; Laird 1968; Nathan 1978). Nathan et al. (1986, fig. 5.13), have illustrated the magnitude and general timing of this structural inversion and the resulting

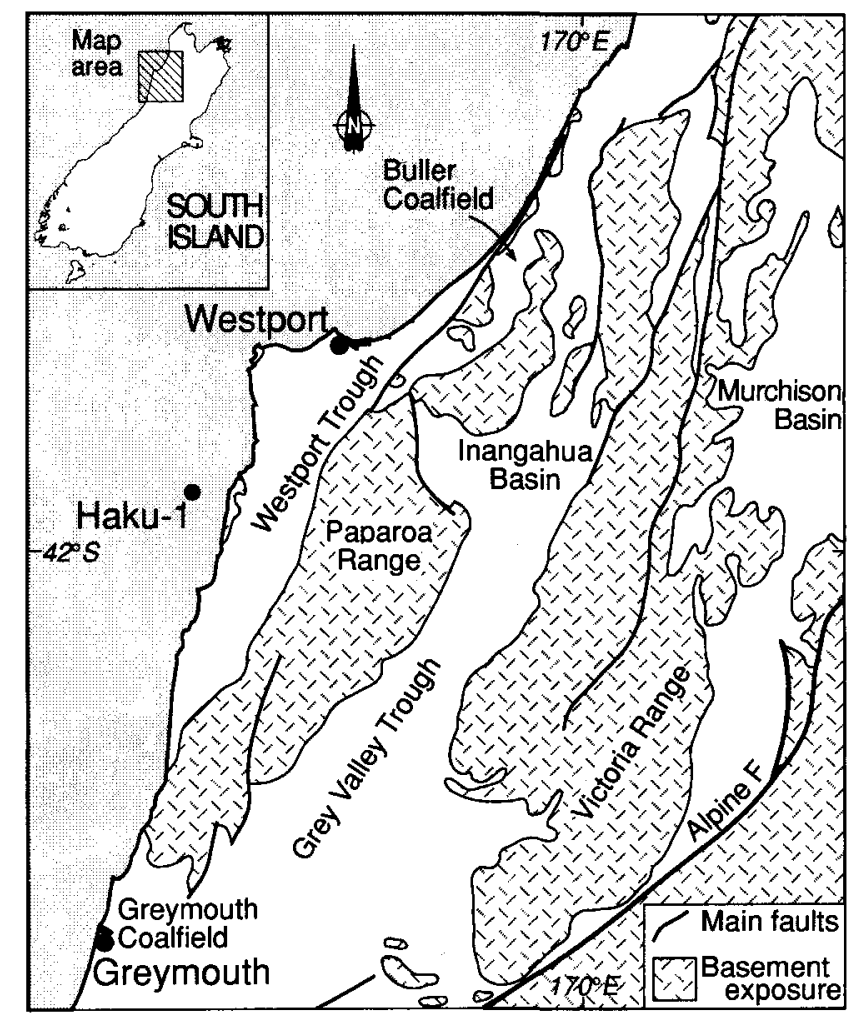

Fig. 1 Structural setting of West Coast, South Island, and the location of Greymouth and Buller Coalfields. 


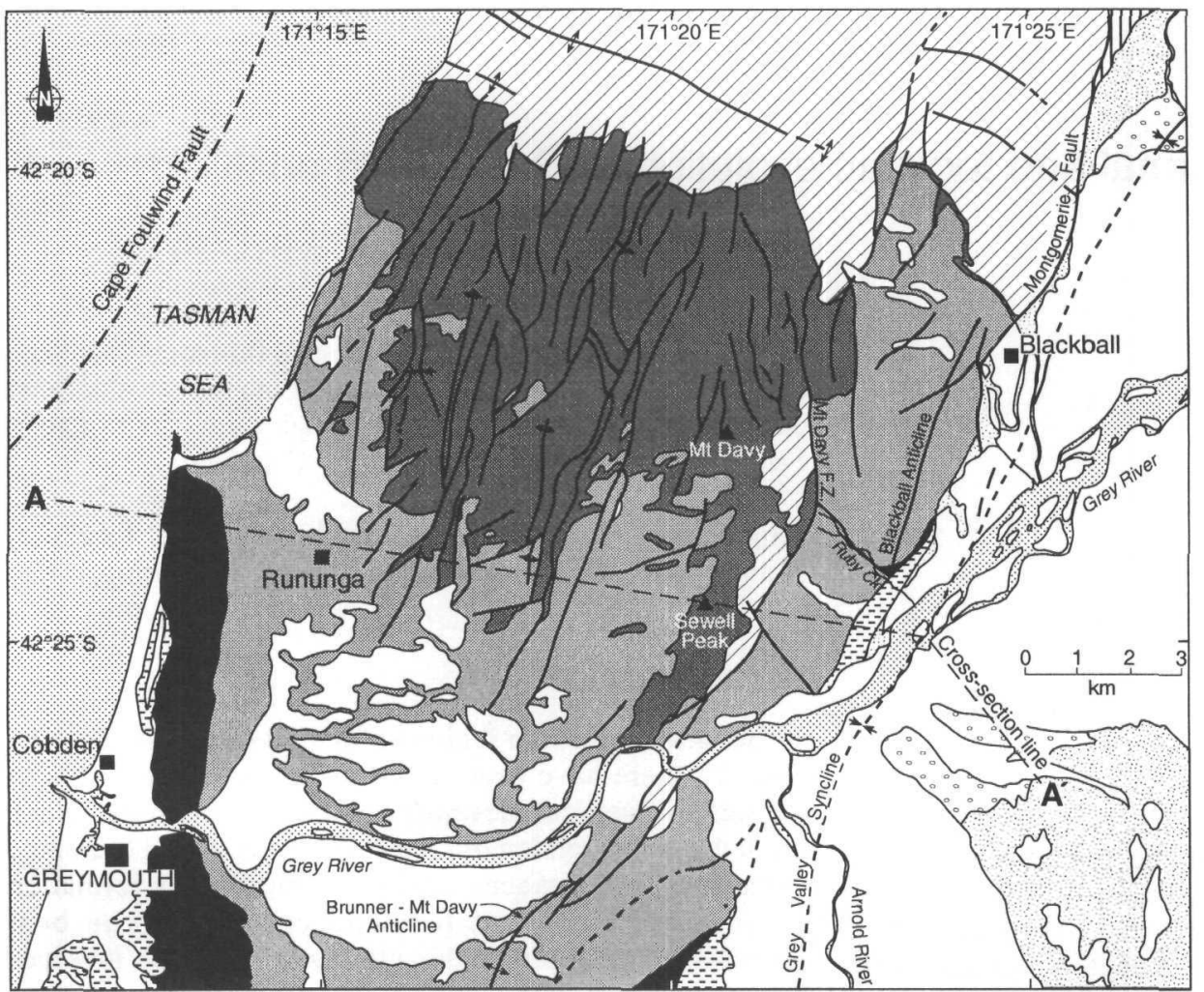

Fig. 2 Geological map of the southern end of the Paparoa Range simplified from part of the Greymouth Sheet S44 (Nathan 1978). Cross section A-A' shown in Fig. 3; cross section line also on Fig. 4 and 11.

MAP KEY

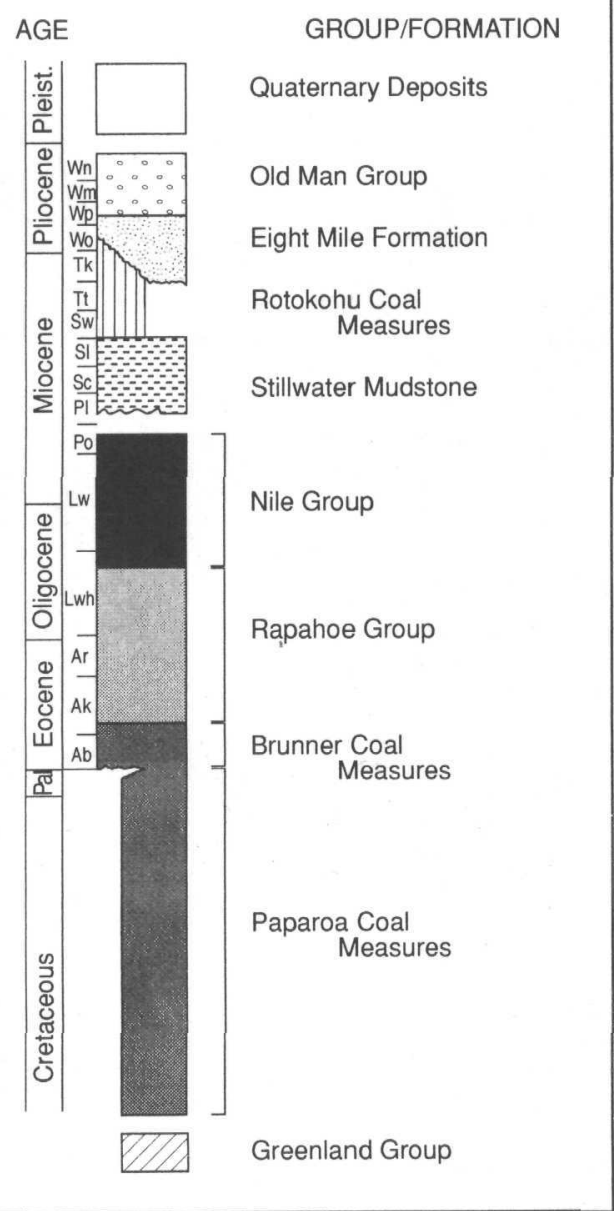

formation and deformation of associated Late CretaceousCenozoic basins.

To better understand the evolution of the structural inversion that has occurred in the Greymouth Coalfield, data are required about the amount and timing of inversion from the zone of uplift and erosion. Traditionally, organic maturation indices have been used to assess the amount of inversion, that is, the amount of stratigraphic section that has been removed by erosion during uplift (e.g., Suggate 1959). It is usually more difficult to establish data on the timing of uplift. Because of the loss of section, rarely can this be established stratigraphically from the inverted basin. Normally this is inferred from the stratigraphic and sedimentologic characteristics of the basin-fill succession in an adjacent basin. Careful mapping (Gage 1952; Nathan 1978) (Fig. 2, 3) and biostratigraphic dating of the western limb of the Grey Valley Syncline has identified and aged three angular unconformities within it. Because this limb is common with the eastern limb of the main inversion structure (Brunner-Mt Davy Anticline), three episodes of uplift and inversion would appear to have occurred, one within the early Miocene, a second during the late Miocene, and a third during the Quaternary.

Although in ideal cases, such as the West Coast example described here, basin stratigraphy can provide some constraints on the timing and episodicity of the neighbouring inversion, a question arises even then as to how complete the description can be. In this West Coast example it can be argued from the deformed (tilted) unconformities within the basin margin (Fig. 2, 3) that the duration of uplift of the Brunner-Mt Davy Anticline must have exceeded the duration of uplift along the basin margin where the unconformities occur, otherwise the observed structure could not have evolved. This idea is tested by application of apatite fission 


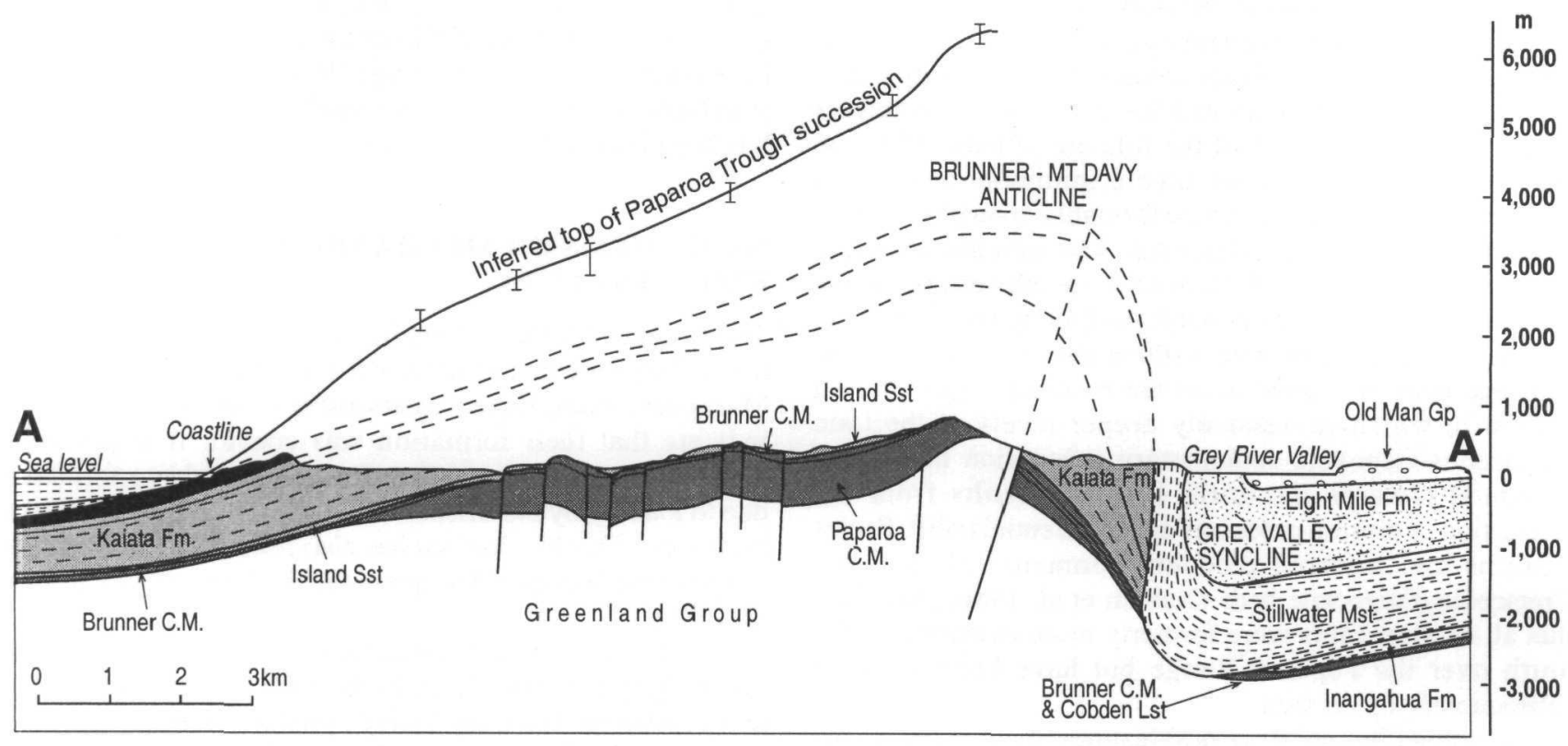

Fig. 3 Cross section through Greymouth Coalfield at the southern end of the Paparoa Range and the axis of the Grey Valley Syncline, simplified from Nathan (1978). Shown as the upper continuous line is the reconstructed top of the Late Cretaceous - late Oligocene sedimentary succession that formerly filled the Paparoa Trough, but which has largely been eroded during the Neogene; calculated from integrated paleotemperature modelling of fission track and vitrinite reflectance data, with maximum paleotemperatures converted to metres using a geothermal gradient value of $29^{\circ} \mathrm{C} / \mathrm{km}$.

track thermochronology to samples from the main zone of inversion (Brunner-Mt Davy Anticline).

\section{TECTONIC SETTING}

The study area is located in Westland at the southern end of the Paparoa Range (Fig. 1). This region lies to the northwest of the Alpine Fault, which is the main structure defining the modern Australia-Pacific plate boundary zone through South Island. Between the Late Cretaceous and the late Oligocene, northwestern South Island underwent two phases of extension. The first of these phases, between c. 80 and 60 $\mathrm{Ma}$, coincided with early seafloor spreading in the Tasman Sea. It resulted in the formation of numerous fault-bounded half grabens and intervening structural highs with axes oriented NNE-SSW. Superb examples of these structures occur in the subsurface of Taranaki Basin (Fig. 1) (e.g., Pilaar \& Wakefield 1978) where they have been deeply buried but largely unaffected by subsequent crustal extension or compression. The same generation of half-grabens formed in northwestern South Island, in which the nonmarine Paparoa Coal Measures accumulated (Laird 1968; Newman \& Newman 1992). Today, the Paparoa Coal Measures, or their equivalents, are restricted chiefly to the Paparoa Range or the northern tip of South Island, but they may formerly have been more extensive. A second phase of extension, which reactivated the Late Cretaceous structures, occurred during the mid Eocene to mid Oligocene and was associated with propagation of the Southeast Indian Ocean Spreading Ridge into southern New Zealand (Kamp 1986a). Much thicker Eocene-Oligocene deposits accumulated in the preexisting half-grabens than in the adjacent regions, which nevertheless foundered below sea level (Nathan et al. 1986). The early Cenozoic deposits accumulated successively in nonmarine (Brunner Coal Measures) littoral (Island Sandstone), inner shelf (Kaiata Fm), and mid to outer shelf (Cobden Limestone) environments (Nathan et al. 1986). Upwards through this succession, terrigenous lithologies give way to marl and skeletal limestones, which indicate passage from active extension to regional subsidence and the inundation of local source areas.

During the earliest Miocene there was a sudden influx of terrigenous mudstone in the West Coast region, and more widely across New Zealand, signalling the rejuvenation of terrigenous source areas associated with inception of the modern plate boundary as a continuous feature through the country (Norris et al. 1978; Kamp 1986b, 1991; Cooper et al. 1987). Soon thereafter, the crustal extension and thinning that had characterised the development of western South Island for the preceding $50 \mathrm{~m}$.y., changed to crustal thickening in response to evolution of the modern plate boundary. This was achieved by reversal of the sense of displacement on virtually all of the pre-existing faults, which caused inversion of the half grabens and the formation, simultaneously, of asymmetrical basins of foreland character over the earlier structural highs. The Neogene crustal shortening in the Buller-northern Westland region has more than restored the Late Cretaceous-Oligocene crustal thinning, as basement underlies prominent ranges that rise to over $1000 \mathrm{~m}$ above sea level.

\section{STRUCTURE AT THE SOUTHERN END OF PAPAROA RANGE}

The southern end of the Paparoa Range is an asymmetrical partially faulted, southward plunging anticlinorium (Gage 1952; Nathan 1978) (Fig. 2, 3). Ordovician sedimentary basement (Greenland Group) comprises the core of the 
structure and is exposed in the north of the map region. To the south, basement is overlain by a sedimentary cover rock succession, with successively younger beds cropping out to the south and wrapping around the fold axis; the youngest beds exposed in the nose of the fold are of latest Miocene age, but these beds do not give a minimum age of the deformation as they are unconformably overlain by late Quaternary fluvio-glacial deposits. The anticline structure is spectacular in the field because the southward plunge is expressed geomorphically: northward along the axis of the fold the elevation rises from $<100 \mathrm{~m}$ above sea level on the Miocene beds, to $>1000 \mathrm{~m}$ on the basement. The outcrop pattern in which successively deeper levels of the Late Cretaceous-Cenozoic sedimentary succession have been exhumed towards the north (Fig. 2) results from the interaction of erosion processes and differential uplift. Facies patterns and inferred paleoenvironments of the Late Cretaceous-Oligocene beds (Nathan et al. 1986), indicates that all of these units were formerly more extensive to the north over the Paparoa Range but have been stripped subsequently by erosion.

Several additional structural features about the anticline and its associated syncline indicate that the increasing uplift to the north was in response to increased amounts of compression, which developed episodically. This is highlighted by describing sequentially segments of the anticline-syncline structure (Fig. 2). (1) Within the segment south of the Grey River, the Brunner-Mt Davy Anticline becomes more asymmetrical towards the north, and at the point where basement appears at the surface the fold axis is faulted. In this segment the eastern limb of the anticline is unconformable with the Miocene section in the Grey Valley Trough. In particular, late-early Miocene terrigenous mudstone (Stillwater Mudstone) overlies late Oligocene marl (Cobden Limestone), and there is a thick Miocene-Pliocene section in the western limb of the Grey Valley Syncline, which contains a late Miocene unconformity. (2) In the segment north of the Grey River to Ruby Creek, the stratigraphic offset on the NNE-striking fault zone increases, and the limb common to the anticline and syncline has a relatively simple structure (see Fig. 2). Increases in dip upward through the Kaiata Formation are consistent with rapid stratigraphic pinchout at the former basin margin. In this segment the whole of the Miocene-Pliocene section is confined to a zone $1.3 \mathrm{~km}$ wide, which is due to the development of three unconformities, the lower one involving the loss of Oligocene and early Miocene beds; the middle one, the loss of middle and late Miocene beds; and the upper one, the loss of late Pliocene and early Pleistocene beds. (3) North of Ruby Creek, the fault zone changes strike, and the main uplift zone is displaced eastward to the Montgomerie Fault. Along much of the Montgomerie Fault, basement is thrust over Pliocene marine beds, having cut out completely the Miocene section, although at the northern end of the fault a late Miocene coal measure succession (Rotokohu Coal Measures) underlies conformably Pliocene marine beds.

The increased interaction between the anticline and syncline northward, along the range front, which is attributed to increased shortening and basement overthrusting, is mirrored in the structure of the western limb of the anticline (Fig. 2). The part of this region north of the Grey River, known as the Greymouth Coalfield, is deformed into two second order NNE-trending anticline-syncline pairs that are disrupted by numerous NNE-striking faults, many of which have reverse displacement (Gage 1952; Nathan 1978). Thest structures do not occur to the south (Fig. 2), where there has been less shortening and uplift.

\section{HYPOTHESIS ON MECHANICS OF RANGE FRONT FAULTING}

The Brunner-Mt Davy Anticline and Grey Valley Syncline: are two asymmetrical structures that have the same vergence. Moreover, stratigraphic relationships summarised above: indicate that their formation was coeval. It is possible: therefore that the Grey Valley Trough formed as a foredeep due to loading by basement overthrust along the range fron! fault zone. This mechanism has also been suggested for the origin of the Westport Trough in the Buller region (Kamp et al. 1996).

In this context, the Neogene angular unconformities that occur along the range front in the limb common to the $\mathrm{M}$ Davy Anticline and Grey Valley Syncline, indicate episodic erosion, subsidence, and sedimentation along the basin margin. A corollary is that the main zone of uplift lying on the western side of the fault zone was probably also uplifted and eroded in phases. This raises a question about the mechanics of displacement on the range front fault zone We hypothesise that the fault zone experienced repeated stick-slip behaviour during each of three phases of compression. This can be argued from the fact that the western limb of the syncline is both deformed as part of the uplifted anticline and comprises marine sediments. Early in each compressive phase when the fault zone was locked. the basin margin sequence may have been tilted, uplifted. and partially eroded. When the fault zone subsequently became unlocked and slipped freely, the basin margin would be loaded by the uplifted block and consequently subside below sea level, thereby creating sediment accommodation. It follows that the duration of each uplift phase must have been longer in the main zone of uplift compared with the basin margin. This can be tested by application of fission track analysis to apatites from the uplifted block, and comparison of the resulting timing of uplift and erosion with the time missing in the unconformities along the basin margin.

\section{APATITE FISSION TRACK THERMOCHRONOLOGY}

Apatite fission track analysis is a method of obtaining thermal history information in sedimentary basins and basement provinces. As well as providing estimates ol maximum paleotemperatures experienced by apatite-bearing! rocks, usually achieved through burial, the technique provides a direct estimate of the time at which a sedimentar: section or basement sequence began cooling, usually via denudation, from its maximum paleotemperature. The basis of the technique, principles of interpretation, and kinetic: modelling have been described in a series of paper: (Gleadow et al. 1983; Green et al. 1986; Laslett et al. 1987: Duddy et al. 1988; Green et al. 1989a). Examples of the application of the technique in sedimentary basins include. Green et al. (1989b) and Kamp \& Green (1990), and in 
hasement provinces include Hurford (1986), Gleadow \& Fitzgerald (1987), and Kamp et al. (1989, 1992).

\section{Experimental procedures}

In this study 139 samples obtained from basement and the overlying sedimentary succession from different parts of both limbs of the Brunner-Mt Davy Anticline were processed, of which 39 samples yielded sufficient apatites for analysis (Table 1). Many of the samples were obtained from cores drilled as part of the Coal Resources Survey. One to $1.5 \mathrm{~kg}$ of sandstone sampled from core was processed, and generally $2 \mathrm{~kg}$ of outcrop sample was processed. Samples with reasonable yields of apatite came chiefly from the Rewanui Member of the Paparoa Coal Measures, and from the Island Sandstone; underlying units were established also by Smale (1978) to contain little if any apatite. The reason for the unusually low yields of apatite from the rocks sampled probably lies in diagenetically controlled processes of dissolution and replacement of the detrital apatite by sulphides, as a result of the evolution of organic acids from the coal measures within the succession during their burial.
Standard procedures were followed (e.g., Green 1985) in processing the apatites and in measuring track densities and lengths. Apatite mounts were irradiated in the X7 Facility of the HIFAR reactor, Lucas Heights, Australia, and the external detector method was used to establish track density and normalise for uranium content of individual crystals. Fission track ages were determined using the zeta calibration method (Hurford \& Green 1982) and the uranium glass standard SRM 612. Track lengths were measured following the recommendations of Laslett et al. (1982). The chlorine contents of selected apatites were established by electron microprobe analysis at the Analytical Facility, Victoria University of Wellington.

\section{Data analysis}

Analytical data are shown in Table 2. Fission track ages were calculated using the standard fission track age equation (Hurford \& Green 1982) with conventional errors (Green 1981), calculated from the total number of tracks counted and reflecting purely poissonian variation, quoted at $\pm 1 \sigma$. The probability of grains counted in a sample belonging to

Table 1 Details of Greymouth Coalfield samples analysed.

\begin{tabular}{|c|c|c|c|c|c|}
\hline Sample & $\begin{array}{l}\text { Map } \\
\text { reference }\end{array}$ & $\begin{array}{l}\text { Drillhole } \\
\text { reference }\end{array}$ & $\begin{array}{c}\text { Sample } \\
\text { elevation (m) }\end{array}$ & $\begin{array}{l}\text { Formation } \\
\text { member }\end{array}$ & $\begin{array}{l}\text { Stratigraphic } \\
\text { age (Stage) }\end{array}$ \\
\hline 8904-01 & J31 675726 & DH621 & 22.7 & Rewanui & late Cret. \\
\hline $8904-02$ & J31 675726 & DH621 & -143.7 & Rewanui & late Cret. \\
\hline $8904-03$ & J31 675726 & DH621 & -273.7 & Rewanui & late Cret. \\
\hline $8904-13$ & K31705719 & DH656 & 308.6 & Rewanui & late Cret. \\
\hline $8904-15$ & K31705719 & DH656 & 94.1 & Morgan & late Cret. \\
\hline $8904-17$ & J3I 684642 & DH654 & -509.7 & Morgan & late Cret. \\
\hline $8904-22$ & $\mathrm{~J} 31 \quad 684642$ & DH654 & -404.5 & Goldlight & Paleocene \\
\hline $8904-24$ & J31 684642 & DH654 & -595.6 & Rewanui & late Cret. \\
\hline $8904-25$ & $\mathrm{~J} 31 \quad 684642$ & DH654 & -711.95 & Rewanui & late Cret. \\
\hline $8904-27$ & K31 735714 & DH659 & 802.0 & Rewanui & late Cret. \\
\hline $8904-28$ & K31 735714 & DH659 & 702.6 & Rewanui & late Cret. \\
\hline $8904-33$ & K31 740647 & outcrop & 660.0 & Dunollie & Paleocene \\
\hline $8904-42$ & $\mathrm{~J} 31676613$ & outcrop & 60.0 & Dunollie & Paleocene \\
\hline $8904-44$ & K31706678 & outcrop & 200.0 & Rewanui & late Cret. \\
\hline $8904-48$ & K31780733 & outcrop & 305.0 & basement & Ordovician \\
\hline $8904-55$ & K31 781675 & outcrop & 80.0 & Eight Mile & $\left(\mathrm{Tk}-\mathrm{Wo}_{\mathrm{o}}\right)$ \\
\hline $8904-57$ & J31 667729 & outcrop & 10.0 & Island Sst & (Kaiatan) \\
\hline $8904-62$ & J31 676749 & outcrop & 5.0 & basement & Ordovician \\
\hline $8904-65$ & $\mathrm{~K} 32715610$ & outcrop & 50.0 & Island Sst & (Kaiatan) \\
\hline $8904-66$ & K32 734618 & outcrop & 40.0 & Island Sst & (Kaiatan) \\
\hline $8904-98$ & K31 708675 & DH630 & 69.0 & Rewanui & late Cret. \\
\hline $8904-107$ & J31 667689 & DH642 & -311.9 & Rewanui & late Cret. \\
\hline $8904-110$ & J31 667644 & DH655 & -215.3 & Island Sst & (Kaiatan) \\
\hline $8904-115$ & K31 707723 & DH663 & 203.0 & Rewanui & late Cret. \\
\hline $8904-119$ & $\mathrm{~J} 31683676$ & DH623 & -104.3 & Rewanui & late Cret. \\
\hline $8904-121$ & $\mathrm{~J} 31687688$ & DH624 & 63.5 & Rewanui & late Cret. \\
\hline $8904-123$ & J31 565692 & DH626 & -333.6 & Rewanui & late Cret. \\
\hline $8904-124$ & K31 707644 & DH627 & -337.6 & Rewanui & late Cret. \\
\hline $8904-125$ & J31 693695 & DH632 & -69.5 & Rewanui & late Cret. \\
\hline $8904-126$ & $\mathrm{~J} 31 \quad 693695$ & DH632 & -151.5 & Rewanui & late Cret. \\
\hline $8904-127$ & $\mathrm{~J} 31 \quad 678710$ & DH635 & -121.1 & Rewanui & late Cret. \\
\hline $8904-128$ & J31 678710 & DH635 & -193.1 & Rewanui & late Cret. \\
\hline $8904-131$ & J31 674702 & DH645 & -206.3 & Rewanui & late Cret. \\
\hline $8904-132$ & J31 674702 & DH645 & -235.3 & Rewanui & late Cret. \\
\hline $8904-133$ & $\mathrm{~J} 31 \quad 687662$ & DH651 & -422.4 & Rewanui & late Cret. \\
\hline $8904-134$ & K31 727726 & DH658 & 394.2 & Rewanui & late Cret. \\
\hline $8904-135$ & K31 735714 & DH659 & 637.6 & Rewanui & late Cret. \\
\hline $8904-136$ & K31 734722 & DH660 & 747.7 & Rewanui & late Cret. \\
\hline $8904-139$ & K31 707713 & DH666 & 219.9 & Rewanui & late Cret. \\
\hline
\end{tabular}

Sample elevation expressed in relation to sea level. Tk is abbreviation for Kapitean Stage, and Wo for Opoitian Stage. 
Table 2 Apatite fission track data for Greymouth Coalfield.

\begin{tabular}{|c|c|c|c|c|c|c|c|c|c|c|c|c|c|}
\hline \multirow[b]{2}{*}{$\begin{array}{l}\text { Sample } \\
\text { no. }\end{array}$} & \multirow[b]{2}{*}{$\begin{array}{l}\text { No. of } \\
\text { crystals }\end{array}$} & \multicolumn{2}{|c|}{ Spontaneous } & \multicolumn{2}{|c|}{ Induced } & \multirow[b]{2}{*}{$\mathrm{P}\left(\chi^{2}\right), \%$} & \multirow[b]{2}{*}{$\begin{array}{l}\rho_{s} / \rho_{i} \\
\pm 1 \sigma\end{array}$} & \multirow[b]{2}{*}{$\rho_{\mathrm{d}}$} & \multirow[b]{2}{*}{$N_{d}$} & \multirow[b]{2}{*}{$\begin{array}{c}\text { Age (Ma) } \\
\pm 1 \sigma\end{array}$} & \multirow{2}{*}{$\begin{array}{l}\text { Mean track } \\
\text { length } \pm 1 \sigma \\
(\mu \mathrm{m})\end{array}$} & \multirow{2}{*}{$\begin{array}{c}\text { Standard } \\
\text { deviation } \\
(\mu \mathrm{m})\end{array}$} & \multirow[b]{2}{*}{$\begin{array}{l}\text { No. of } \\
\text { lengths }\end{array}$} \\
\hline & & $\rho_{\mathrm{s}}$ & $\mathrm{N}_{\mathrm{s}}$ & $\rho_{i}$ & $\mathrm{~N}_{\mathrm{i}}$ & & & & & & & & \\
\hline 8904-01 & 23 & 0.483 & 467 & 2.003 & 1937 & 0.0 & $0.283 \pm 0.031$ & 0.875 & 8293 & $36.8 \pm 3.5$ & $10.42 \pm 0.20$ & 1.85 & 86 \\
\hline $8904-02$ & 25 & 0.491 & 297 & 2.344 & 1419 & 0.0 & $0.259 \pm 0.033$ & 0.875 & 8293 & $35.6 \pm 4.5$ & $10.10 \pm 0.70$ & 2.97 & 18 \\
\hline $8904-03$ & 22 & 0.499 & 247 & 1.536 & 760 & 12.5 & - & 0.875 & 8293 & $49.4 \pm 3.7$ & 8.76 & - & 1 \\
\hline $8904-13$ & 25 & 0.126 & 62 & 1.254 & 616 & 87.3 & - & 0.875 & 8293 & $15.3 \pm 2.1$ & $12.51 \pm 1.07$ & 1.85 & 3 \\
\hline $8904-15$ & 19 & 0.248 & 385 & 2.899 & 4494 & 10.1 & _- & 0.875 & 8293 & $13.1 \pm 0.7$ & $12.48 \pm 0.30$ & 2.08 & 48 \\
\hline $8904-17$ & 20 & 0.061 & 28 & 0.312 & 144 & 98.9 & - & 0.875 & 8293 & $29.6 \pm 6.1$ & 13.94 & - & 1 \\
\hline $8904-22$ & 9 & 0.161 & 48 & 2.224 & 662 & 1.5 & $0.105 \pm 0.033$ & 0.875 & 8293 & $12.5 \pm 2.5$ & $11.46 \pm 1.52$ & 2.63 & 3 \\
\hline $8904-24$ & 8 & 0.238 & 124 & 4.611 & 2407 & 5.3 & - & 0.944 & 4472 & $8.5 \pm 0.8$ & - & - & - \\
\hline $8904-25$ & 16 & 0.109 & 69 & 2.821 & 1781 & 48.4 & - & 0.938 & 4448 & $6.3 \pm 0.8$ & $9.90 \pm 1.33$ & 2.97 & 5 \\
\hline $8904-27$ & 9 & 0.179 & 34 & 3.890 & 740 & 15.6 & - & 0.933 & 4423 & $7.5 \pm 1.3$ & $13.57 \pm 0.40$ & 0.70 & 3 \\
\hline $8904-28$ & 19 & 0.168 & 136 & 2.771 & 2249 & 65.9 & _- & 0.928 & 4398 & $9.8 \pm 0.9$ & $13.10 \pm 0.32$ & 1.57 & 24 \\
\hline $8904-33$ & 8 & 0.046 & 16 & 0.728 & 252 & 100.0 & - & 0.923 & 4374 & $10.2 \pm 2.6$ & - & - & - \\
\hline $8904-42$ & 6 & 0.539 & 76 & 3.356 & 473 & 77.8 & - & 0.907 & 4267 & $25.4 \pm 3.2$ & $9.69 \pm 0.81$ & 2.30 & 9 \\
\hline $8904-44$ & 17 & 0.248 & 195 & 4.168 & 3277 & 9.6 & - & 0.902 & 4275 & $9.4 \pm 0.7$ & $12.56 \pm 0.32$ & 1.79 & 31 \\
\hline $8904 \quad 48$ & 20 & 0.172 & 91 & 2.065 & 1091 & 11.7 & - & 0.897 & 4250 & $13.0 \pm 1.4$ & $11.76 \pm 0.50$ & 1.66 & 11 \\
\hline $8904-55$ & 20 & 0.463 & 194 & 1.668 & 699 & 14.2 & _. & 0.892 & 4226 & $43.0 \pm 3.6$ & $12.99 \pm 0.20$ & 0.98 & 24 \\
\hline $8904-57$ & 20 & 0.649 & 153 & 2.291 & 33.9 & 2.6 & $0.337 \pm 0.041$ & 0.886 & 4201 & $47.3 \pm 6.0$ & $12.24 \pm 0.20$ & 0.87 & 19 \\
\hline $8904-62$ & 20 & 0.891 & 129 & 3.026 & 438 & 94.1 & - & 0.881 & 4176 & $45.1 \pm 4.6$ & $11.10 \pm 0.50$ & 1.66 & 11 \\
\hline $8904-65$ & 18 & 0.144 & 50 & 2.010 & 700 & 77.0 & - & 0.876 & 4151 & $10.9 \pm 1.6$ & $8.43 \pm 1.93$ & 3.34 & 3 \\
\hline $8904-66$ & 18 & 0.150 & 56 & 1.526 & 568 & 97.3 & - & 0.871 & 4127 & $15.0 \pm 2.1$ & $11.80 \pm 0.73$ & 2.63 & 13 \\
\hline 8904-98 & 19 & 0.265 & 185 & 3.489 & 2432 & 19.7 & - & 0.866 & 4102 & $11.5 \pm 0.9$ & $10.36 \pm 0.40$ & 2.40 & 36 \\
\hline $8904-107$ & 20 & 0.561 & 265 & 3.103 & 1465 & 79.8 & - & 0.860 & 4078 & $27.1 \pm 1.9$ & $8.60 \pm 0.68$ & 2.36 & 12 \\
\hline $8904-110$ & 13 & 0.575 & 114 & 4.339 & 861 & 0.0 & $0.201 \pm 0.029$ & 0.855 & 4053 & $26.7 \pm 4.1$ & $12.09 \pm 1.02$ & 1.02 & 2 \\
\hline $8904-115$ & 20 & 0.106 & 34 & 1.782 & 571 & 0.0 & $0.092 \pm 0.038$ & 0.719 & 3408 & $9.6 \pm 2.9$ & $13.31 \pm 1.07$ & 2.62 & 6 \\
\hline $8904-119$ & 9 & 0.132 & 21 & 1.652 & 262 & 26.2 & - & 0.732 & 3470 & $10.2 \pm 2.3$ & - & - & - \\
\hline $8904-121$ & 20 & 0.218 & 247 & 2.279 & 2578 & 3.0 & $0.102 \pm 0.010$ & 0.739 & 3501 & $12.5 \pm 1.1$ & $10.13 \pm 0.50$ & 2.18 & 19 \\
\hline $8904-123$ & 20 & 0.259 & 145 & 1.297 & 727 & 0.0 & $0.215 \pm 0.035$ & 0.745 & 3532 & $25.9 \pm 3.9$ & $10.89 \pm 0.53$ & 1.40 & 8 \\
\hline $8904-124$ & 20 & 0.157 & 161 & 3.140 & 3219 & 73.0 & - & 0.752 & 3562 & $6.6 \pm 0.5$ & $12.01 \pm 0.30$ & 1.20 & 16 \\
\hline $8904-125$ & 20 & 0.233 & 251 & 2.763 & 2983 & 0.0 & $0.094 \pm 0.021$ & 0.758 & 3593 & $11.4 \pm 2.3$ & $13.02 \pm 0.86$ & 1.92 & 5 \\
\hline $8904-126$ & 20 & 0.100 & 80 & 1.904 & 1528 & 89.3 & - & 0.764 & 3624 & $7.0 \pm 0.8$ & $11.33 \pm 0.54$ & 1.08 & 4 \\
\hline $8904-127$ & 22 & 0.102 & 66 & 1.275 & 822 & 0.3 & $0.114 \pm 0.026$ & 0.771 & 3655 & $12.3 \pm 2.3$ & - & - & - \\
\hline $8904-128$ & 20 & 0.164 & 85 & 1.609 & 833 & 50.1 & - & 0.776 & 3686 & $13.8 \pm 1.6$ & 14.59 & - & 1 \\
\hline $8904-131$ & 19 & 0.129 & 35 & 1.228 & 333 & 95.7 & - & 0.784 & 3717 & $14.4 \pm 2.6$ & $9.11 \pm 1.15$ & 1.63 & 3 \\
\hline $8904-132$ & 19 & 0.141 & 40 & 0.946 & 269 & 44.7 & - & 0.790 & 3747 & $20.4 \pm 3.5$ & $10.51 \pm 0.83$ & 2.35 & 8 \\
\hline $8904-133$ & 20 & 0.175 & 88 & 2.738 & 1381 & 0.0 & $0.121 \pm 0.027$ & 0.800 & 3778 & $12.8 \pm 2.4$ & $9.88 \pm 0.64$ & 0.64 & 2 \\
\hline $8904-134$ & 12 & 0.057 & 17 & 1.346 & 398 & 73.5 & - & 0.804 & 3809 & $6.0 \pm 1.5$ & 12.43 & - & 1 \\
\hline $8904-135$ & 16 & 0.200 & 106 & 3.031 & 1609 & 54.5 & _- & 0.810 & 3839 & $9.3 \pm 1.0$ & $13.32 \pm 0.53$ & 1.50 & 8 \\
\hline $8904-136$ & 20 & 0.138 & 67 & 2.784 & 1348 & 39.1 & - & 0.817 & 3870 & $7.1 \pm 0.9$ & $12.94 \pm 0.64$ & 1.43 & 5 \\
\hline 8904-139 & 20 & 0.276 & 209 & 3.736 & 2831 & 0.4 & $0.070 \pm 0.008$ & 0.823 & 3901 & $10.5 \pm 1.3$ & $12.26 \pm 0.58$ & 2.56 & 21 \\
\hline
\end{tabular}

Track densities $(\rho)$ are $\times 10^{6}$ tracks $\mathrm{cm}^{-2}$. All analyses are by the External Detector Method using 0.5 for the $4 \pi / 2 \pi$ geometry correction factor. Apatite ages calculated using dosimeter glass SRM

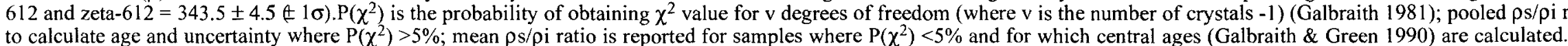


Fig. 4 Greymouth Coalfield showing details of sample locations, sample numbers, and apatite fission track ages $(\mathrm{Ma} \pm 1 \sigma$ errors).

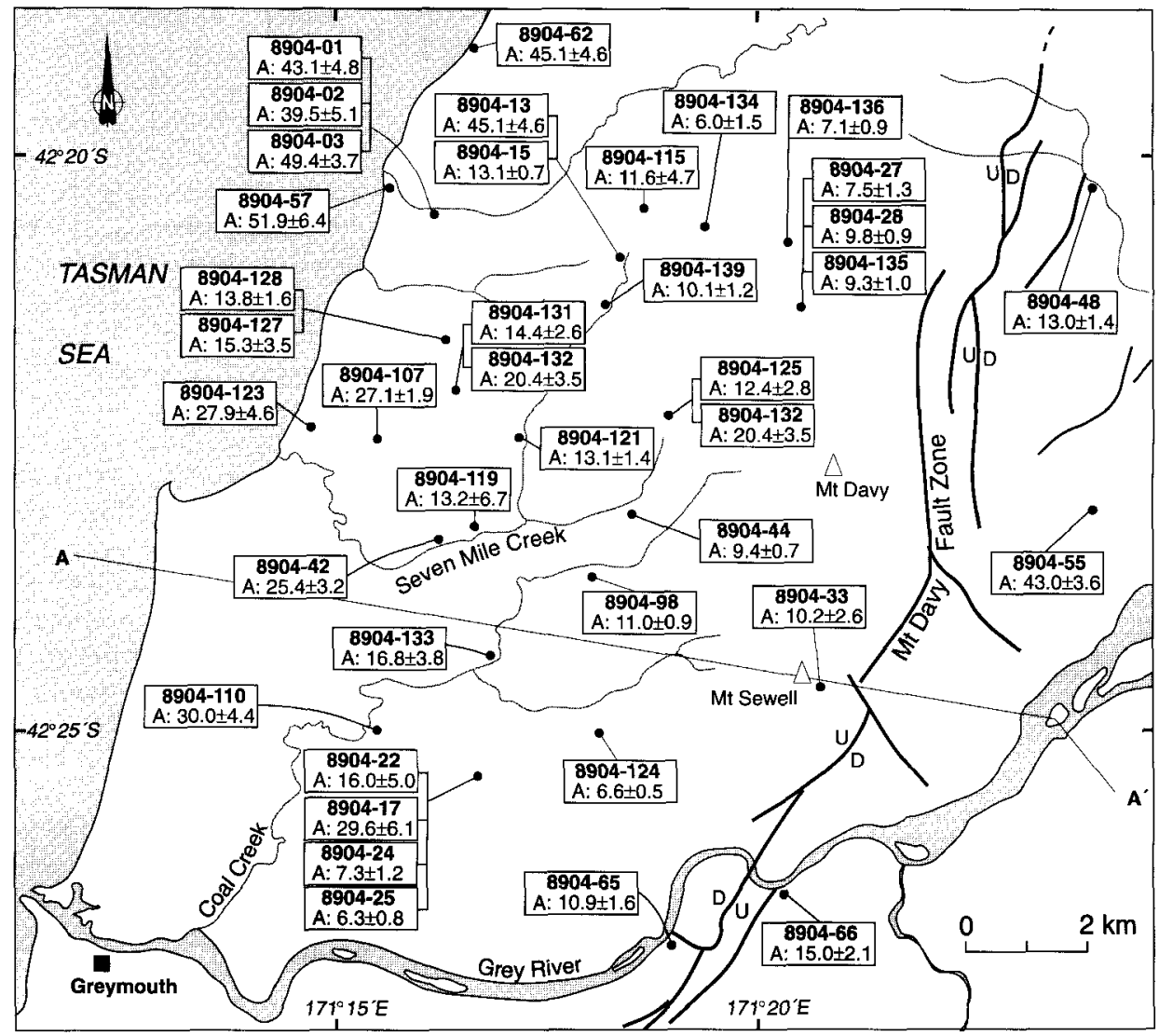

a single population of ages is assessed by a chi-squared statistic (Galbraith 1981). A probability of $<5 \%$ is taken as evidence that the grains represent a mixed population, and a central age is given in Table 2 .

\section{RESULTS AND INTERPRETATIONS}

Apatite fission track age and length data for samples from the field area are given in Table 2. A limitation of the data is the generally low number of confined track length measurements that could be made for each sample. This arises from the low track densities, as reflected in the mainly Neogene apparent ages, and the poor apatite yields and quality. All interpretations involving the length data are therefore more liberal and less certain than would be the case if 100 lengths were measured.

The sample ages in relation to the sample sites are shown in Fig. 4. The systematic changes in the fission track data across the coalfield are best illustrated in a series of cross sections, one each for the northern, central, and southern parts of the coalfield, in which sample mean age and mean length are plotted with respect to distance from the Mt Davy Fault Zone. The data are plotted against distance from the Mt Davy Fault Zone because the upper crustal section and paleoisotherms have been tilted (westward), akin to the crust underlying the Southern Alps (Kamp et al. 1989), and much of the section has been eroded.

Fission track parameters for sample horizons now at or near Earth's surface will reflect the total thermal history experienced since track accumulation started for a particular mineral system, in this case apatite. While heating of sedimentary rocks is generally associated with burial, cooling is usually achieved by denudation or erosion, resulting in exhumation of host rocks. In the case of the Greymouth Coalfield, the timing and rate of denudation/ erosion will match the timing and rate of rock uplift. This arises because the cooling involved chiefly erosion of sedimentary section that accumulated within the Paparoa Trough during the late Eocene and Oligocene. The thickest unit eroded is the Kaiata Mudstone (Nathan 1978), which is particularly unstable and is prone to failure by mass movement. Significant topography could not develop in this unit, as evidenced by the occurrence of high-grade Brunner and Paparoa Coal Measures at or near the surface. Only when the inversion brought the basement (Greenland Group) to the surface during the Quaternary could significant topography (Paparoa Range) develop, and the rates of uplift decoupled to some extent from those of denudation.

\section{Northern region}

In Fig. 5 the apatite fission track ages reduce from c. $50 \mathrm{Ma}$ for samples near the coast to a minimum of $6 \mathrm{Ma}$ some 4 $5 \mathrm{~km}$ west of the Mt Davy Fault Zone. One sample (890448) further east has a higher age of $13.0 \pm 1.4 \mathrm{Ma}$. In each sample in this transect the fission track age is less than the stratigraphic age of the unit sampled, indicating that all samples have been subjected to higher paleotemperatures following deposition. The form of the age profile is similar to the pattern typically obtained down a well section that has undergone some cooling through uplift and erosion (e.g., Fresne-1, Taranaki Basin; Kamp \& Green 1990): the interval of pronounced age reduction corresponds to an exhumed 

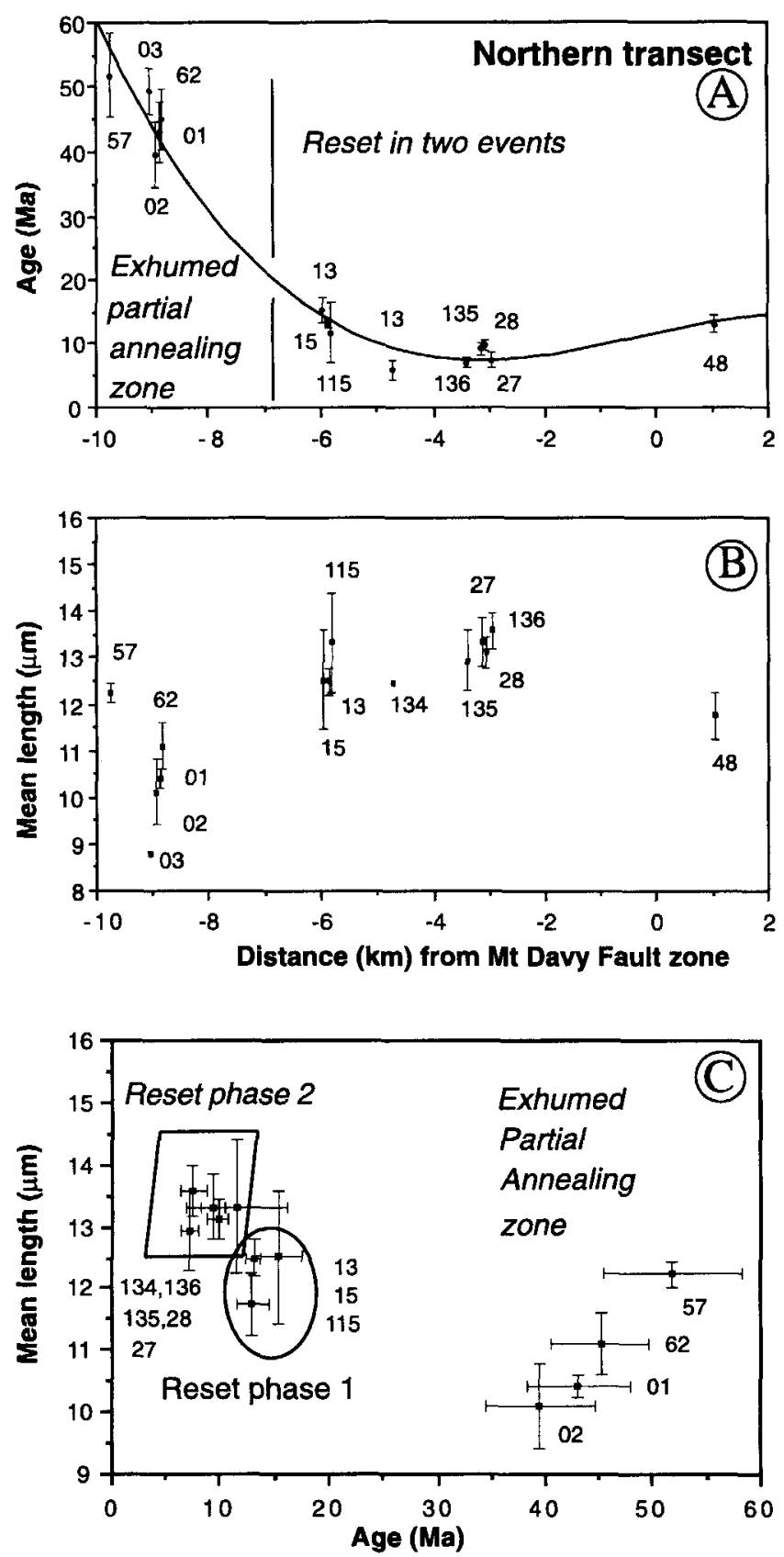

Fig. 5 Mean fission track age (A) and mean track length (B) for samples from the northern part of the Greymouth Coalfield illustrated with respect to distance from the Mt Davy Fault. In (C) the same data are shown as mean fission track length versus age. See text for discussion.

partial annealing zone (PAZ) (10-7 km west of Mt Davy Fault Zone) and the plateau interval corresponds to sediments buried (heated) to depths and temperatures above the resetting temperature of fission tracks in apatite.

Track length data suggest that all of the samples have formerly experienced elevated paleotemperatures, some coinciding with middle to lower parts of an apatite fission track partial annealing zone, and others coinciding with temperatures at which tracks are completely annealed and the thermochronometer is reset. On the mean length versus age plot (Fig. 5C) the samples that resided within the PAZ are identified by their older age and shorter lengths. Within this zone samples sequentially closer to the Mt Davy Fault Zone have correspondingly shorter mean track lengths. This is consistent with the more easterly samples having resided formerly at deeper levels in the exhumed PAZ. The samples from the reset zone have noticeably longer mean length: than the samples from the exhumed PAZ. In summary, the general pattern of the fission track data in the northern transect indicates that sediments now at or near the surfact: were heated to progressively higher temperatures eastward across the coalfield to the fault zone; a corollary is that the degree of subsequent inversion also increased eastward to the fault zone.

Within the zone of reset samples there are two discret: groupings that indicate details about the denudation history Samples originating a few kilometres west of the fault zone have younger ages and longer mean lengths than samples originating further west from the fault zone which have older ages and shorter mean lengths (Fig. 5C). These group possibly result from two separate denudation phases. The first uplift phase would have caused initial cooling of the partial annealing zone now fossilised in the western part $c$; the coalfield, but the direct evidence is only recorded in is narrow zone c. $2 \mathrm{~km}$ wide immediately east of the base ct the exhumed PAZ (samples 8904-13, 15, and 115). Thest samples had earlier been heated via burial to temperature: just above the base of the annealing zone, and woulc therefore be the first sample apatites in the reset zone to be able to accumulate tracks after cooling via uplift and erosion started. That only a narrow zone of the coalfield records the first phase of cooling suggests that the denudation wa probably limited to $<1 \mathrm{~km}$ in that part of the coalfield. Whil this amount of uplift and erosion was sufficient to cool thes: rocks to allow track retention to begin, they resided nevertheless at elevated temperatures within a PAZ until the were cooled further by a second phase of uplift and erosion The second group of sample host rocks from more eastern areas $(8904-27,28,134,135$, and 136) would have beer uplifted and exhumed during the first phase, but at that time: did not cool sufficiently to enter the PAZ and hence start to retain a track record of uplift; this would have happened during the second uplift and erosion phase. Sample 8904 48 from east of the Mt Davy Fault Zone groups with the reset samples furthest west from the fault zone, and indicate: that parts of the eastern limb of the anticline also cooled into the zone of track retention during the first denudaticn phase.

\section{Central region}

The patterns of the fission track data in the central region of the coalfield are similar to those in the northern transect, and are interpreted in a similar fashion. Based on the mean length-age relationship of the samples (Fig. 6C), the bas of the exhumed PAZ is placed at $8 \mathrm{~km}$ west of the Mt Dav. Fault Zone, all of the samples to the east having been heate sufficiently to reset the track density. On the mean lengthage plot, two groups emerge within the reset samples, one indicating denudation and exhumation started during the early Miocene (phase 1), and the other indicating denudation and exhumation started in the late Miocene (phase 2).

\section{Southern region}

The fission track data for the southern part of the coalfield also identify a western-exhumed PAZ and an eastern zone 

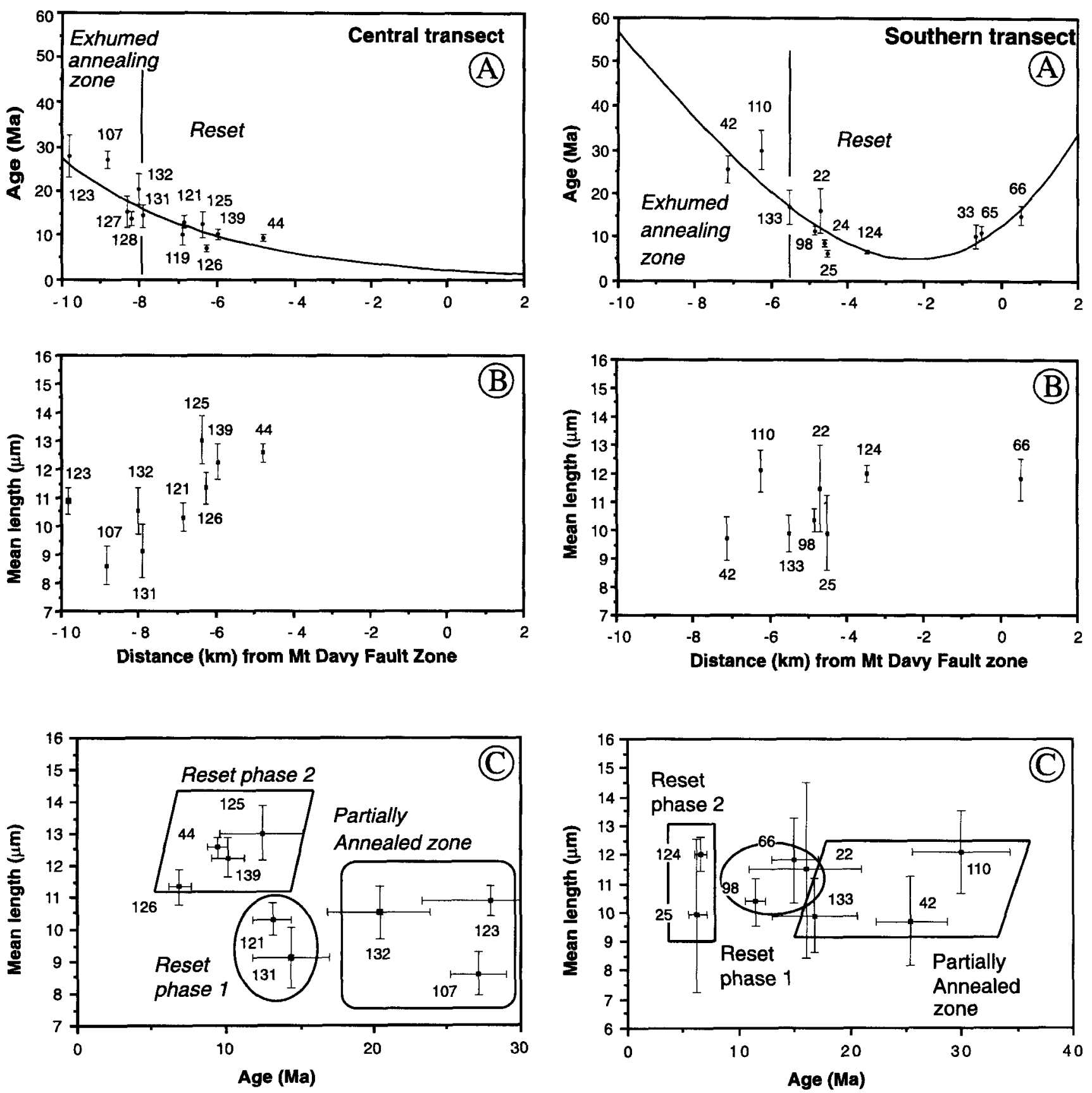

Fig. 6 Mean fission track age (A) and mean track length (B) for samples from the central part of the Greymouth Coalfield illustrated with respect to distance from the Mt Davy Fault. In (C) the same data are shown as mean fission track length versus age. See text for discussion.

of reset ages, which involves both the western and eastern limbs of the Brunner-Mt Davy Anticline (Fig. 7). As with the other transects, there are two groups within the reset samples, one that started to accumulate tracks during the early Miocene around $18 \mathrm{Ma}$, and another that started to accumulate tracks from the late Miocene. In this transect the group of samples with the youngest ages have shorter mean track length values than samples with the youngest ages further north in the coalfield. This is considered to be due to the plunging anticline structure. Here the host rocks have much lower elevations than equivalent stratigraphic

Fig. 7 Mean fission track age (A) and mean track length (B) for samples from the southern part of the Greymouth Coalfield illustrated with respect to distance from the Mt Davy Fault. In (C) the same data are shown as mean fission track length versus age. See text for discussion.

units sampled further north in the coalfield, and therefore they have cooled more slowly through the modern annealing zone during the final (Quaternary) denudation phase, which has resulted in a greater degree of annealing.

\section{Apatite composition}

Apatite composition, specifically chlorine content, is known to have a control on the annealing properties of latent fission tracks (Green et al. 1986). Chlorapatite crystals are more retentive of tracks than fluorapatites when they reside in a partial annealing zone. An effect of the compositional control 
on annealing is that the temperature of the base of the partial annealing zone will vary depending on the particular composition of the apatites being analysed from a field area.

To constrain the temperature at which the apatites were reset in the Greymouth Coalfield and the paleotemperature modelling, the chlorine contents of apatites in seven samples from different stratigraphic units and parts of the coalfield were determined by microprobe analysis. The results are given in Table 3. The detectable limit of the JEOL superprobe (Analytical Facility, Victoria University of Wellington) for chlorine is c. $0.05 \mathrm{wt} \%$. Only $23 \%$ of the grains across all samples have a chlorine content $>0.1 \%$, and all but $10 \%$ of these grains occur in one sample (8904-110). Excluding sample $8904-110$, the sample mean values range from 0.026 to $0.323 \mathrm{wt} \%$ chlorine (Table 3 ). The majority of the apatites are therefore fluorapatites, consistent with the granitic source of much of the Rewanui Member.

The particular grains microprobed for chlorine composition were also the grains analysed for track density (age). In the four samples from the reset zone (8904-27, 44, 131, and 139) there is a slight trend for age to be positively correlated with chlorine content, but generally the range of chlorine contents is low, often strictly below the detectability limit of the microprobe. All but sample 8904-139 passed the chi-squared test. In the samples from the partial annealing zone (8904-42 and 110) age is positively correlated with chlorine content, strongly in the case of 8904-110, but this is opposite to that in sample $8904-123$, which has one outstanding grain with higher chlorine content $(0.246 \mathrm{wt} \%)$ but little age (Fig. 8). Sample 8904-110 is the only one with apatites showing a large range of chlorine contents. All the other samples come from the Rewanui Member, whereas 8904-11 comes from late Eocene Island Sandstone, which was probably sourced from a greater range of basement types than the Rewanui Member. Samples 8904-42 and 110 were heated to lower levels (higher temperatures) in the exhumed partial annealing zone (Fig. 7) probably to temperatures of $90^{\circ} \mathrm{C}$ or higher. This would have allowed the more fluorinerich apatites in these samples to become more heavily annealed than the chlorine-rich grains. Sample 8904-110 failed the chi-squared test, but $8904-42$ passed, perhaps reflecting the greater uncertainty associated with its single grain ages.

\section{Timing of cooling and inversion}

The timing of denudation within the anticline structure cannot be estimated directly from the fission track ages of the reset samples, because some track density and thus age will have been lost due to shortening of tracks as the samples resided within, and passed through a partial annealing zone. Via a length-density relationship (Green 1988), measured

Table 3 Composition of apatite, Greymouth Coalfield.

\begin{tabular}{lcccl}
\hline Sample & $\begin{array}{c}\text { Mean wt\% } \\
\text { chlorine }\end{array}$ & $\begin{array}{c}\text { Range } \\
(\text { wt } \% \text { Cl) }\end{array}$ & $\begin{array}{r}\text { No. of } \\
\text { crystals }\end{array}$ & $\begin{array}{c}\text { Stratigraphic } \\
\text { unit }\end{array}$ \\
\hline $8904-27$ & 0.066 & $0.004-0.353$ & 9 & Rewanui \\
$8904-42$ & 0.026 & $0.000-0.060$ & 6 & Rewanui \\
$8904-44$ & 0.057 & $0.002-0.155$ & 15 & Rewanui \\
$8904-110$ & 0.308 & $0.009-0.630$ & 12 & Island Sst \\
$8904-123$ & 0.043 & $0.001-0.246$ & 8 & Rewanui \\
$8904-131$ & 0.028 & $0.001-0.144$ & 14 & Rewanui \\
$8904-139$ & 0.042 & $0.007-0.120$ & 18 & Rewanui \\
\hline
\end{tabular}

ages can be corrected for this track length reduction. Thi procedure establishes approximately the age at which the respective host rocks cooled below the base of an apatit. partial annealing zone $\left(100-110^{\circ} \mathrm{C}\right)$. The corrected age: reported here were derived from a slight modification 0 : the length-density relationship reported by Green (1988) Fifteen micrometres was taken as the mean track lengt corresponding to no reduced track density (age reduction); This compensates for the shorter length of spontaneou* tracks in age standards versus induced track lengths. Onl samples with mean track lengths of about $11.5 \mu \mathrm{m}$ or longe: were length-corrected. Errors on the corrected ages wer: estimated statistically by combining the errors associate: with the observed sample ages and those surrounding the sample mean lengths.

The results of age correction are illustrated in a frequenc: distribution built up for $1 \mathrm{~m} . \mathrm{y}$. divisions based on the 20 range of ages for each length-corrected sample age (Fig. 9 ) The graph shows two modes, one centred on 20-15 Ma and another on 12-7 Ma. Assuming that the uplift and erosion during each phase was not instantaneous, the frequenc distribution potentially represents a mixture of natura variability in the data, the effects of intersample difference in apatite composition on track annealing, and reak differences in age of uplift (strictly denudation) initiation across and along the inversion structure. Because there ar: only minor differences in apatite composition of the sample: probed (Table 3 ), the composition factor is unlikely to caus: much of the observed variability in the corrected ages. $A$ frequency level of 4 to 5 is taken to separate the inheren! variability in the data from the real age range of uplift and denudation associated with each phase of deformation. Uplit: and erosion before $20 \mathrm{Ma}$ (early Otaian Stage) would not be consistent with the late Oligocene accumulation of Cobden Limestone in the Paparoa Trough. Conversely, $\mathrm{t}_{\mathrm{i}}:$ occurrence of siltstones of Otaian age along the westem margin of the Grey Valley Syncline suggests that region:i: shortening had started by 19-20 Ma and before the Altonan Stage. If the interpretations are right, the first phase of uplitt and erosion extended from c. $20 \mathrm{Ma}$ until c. $15 \mathrm{Ma}$, and the second phase extended from c. $12 \mathrm{Ma}$ until c. $7 \mathrm{Ma}$. In addition to the two Miocene uplift and erosion phases, ther was a late Pliocene-Pleistocene uplift phase, although there is no direct fission track evidence for it. Substantial post-. early Pliocene uplift is required from the $\operatorname{dip}\left(45-60^{\circ} \mathrm{C}\right)$ of the Pliocene Eight Mile Formation and overlying ear Pleistocene Old Man Group in the western limb of the Gre Valley Syncline (Nathan 1978). Indeed, it has been suggeste that the present basin-and-range topography originated during the latest Cenozoic (Nathan et al. 1986). This is consistent with the fission track data, as a recent and maju. uplift-denudation phase is required for the evidence for th: two earlier phases to be accessible in surface or near-surfac: samples.

\section{Paleotemperature modelling}

The apatite fission track data reported above have been quantitatively modelled in a forward manner, as describe 1 by Green et al. (1989a), to estimate the maximum temperatures experienced by the host rocks during burial, and to constrain the style of cooling. By assuming a geothermal gradient at the time of maximum burial, ard during cooling, the results of the modelling lead to an 
Fig. 8 Individual grain fission track age versus wt $\%$ chlorine content for apatites within seven different samples. Sample 890427 is from the northern region, samples 8904-131, 139, 44, and 123 are from the central region, and samples $8904-42$ and 110 are from the southern region of the coalfield.
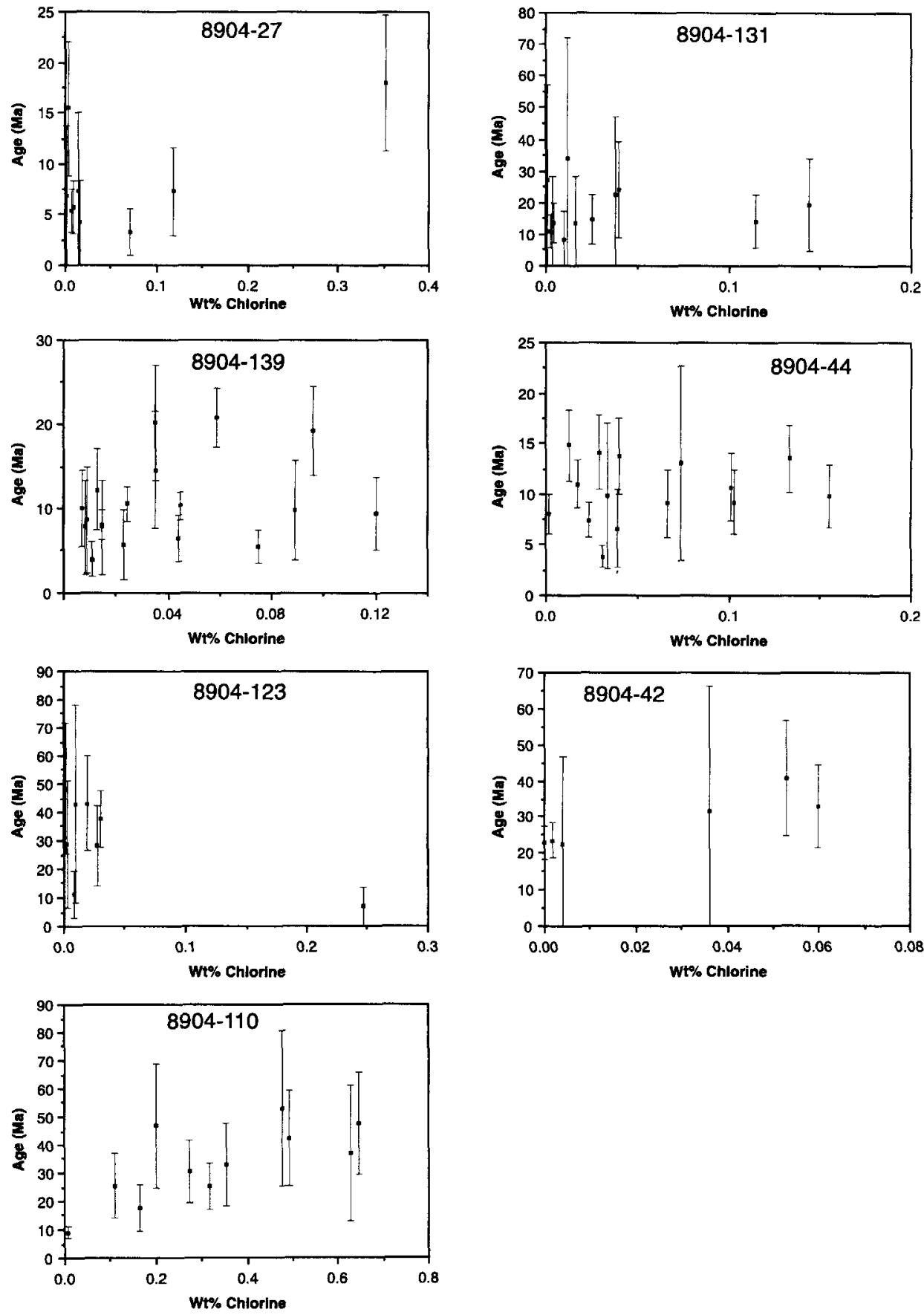

improved estimate of the total amount of uplift and erosion across the anticline, and provide limits on the amount of uplift during each of the three phases of uplift.

The forward modelling was undertaken using software developed by Geotrack International Pty Ltd., based on laboratory-scale fission track kinetic data and long-term geological control data for multiple apatite compositions (Green et al. 1989a; Duddy et al. 1991). The range of compositions used in the modelling comprised the actual $\mathrm{Cl}$ contents of the sample apatites for respective samples and geological units, as reported in Table 3 . The VR data available for the coalfield (Bowman 1984; Boyd \& Lewis 1995) were modelled using the Burnham \& Sweeney (1989) formulation via the thermal history framework of the fission track model described by Duddy et al. (1991) and Bray et al. (1992). A surface temperature of $15^{\circ} \mathrm{C}$, and a geothermal gradient of $29^{\circ} \mathrm{C} / \mathrm{km}$, the value for hydrocarbon wells in the region (Armstrong et al. 1996) were used in estimating formation temperatures for the shallow drillhole samples.

The modelling procedure involved inputting stratigraphic constraints pertaining to the burial history in the Paparoa Trough. The timing of the cooling history was constrained by the age limits of the discrete cooling/uplift phases identified by length correction of the reset fission track ages (Phase 1, 20-15 Ma; Phase 2, 12-7 Ma; Phase 3, 2-0 Ma). In addition, vitrinite reflectance (VR) data available for the coalfield (Fig. 10) were quantitatively modelled using the Burnham \& Sweeney (1989) description of increase in VR as a function of temperature and time. There is a very close agreement between observed and predicted VR values when 

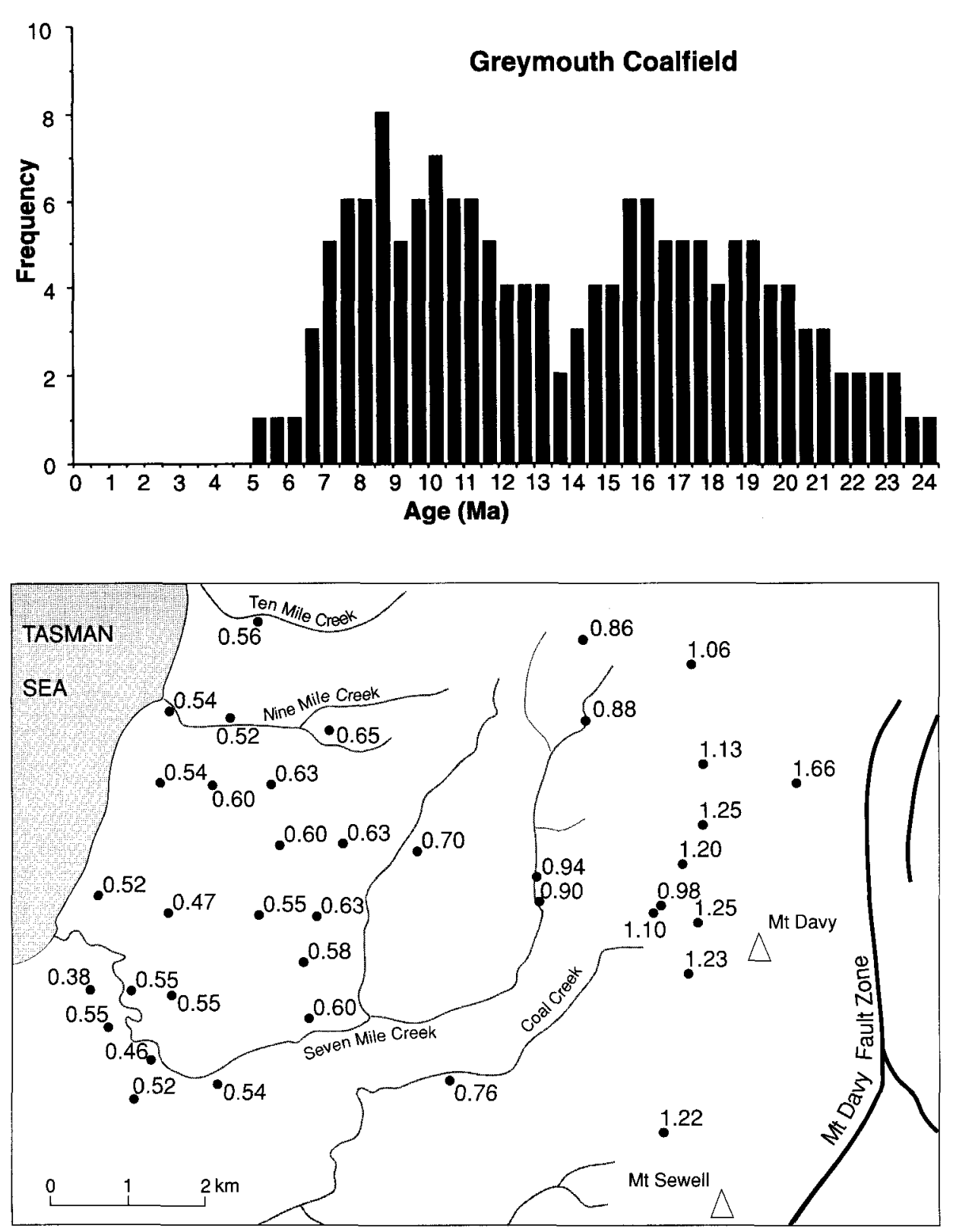

Fig. 9 The frequency of lengthcorrected apatite fission track age that constrain the duration 0 : discrete uplift-erosion phases $\mathrm{i}$ the Greymouth Coalfield. Th. data identify early Miocene ( 20 . $15 \mathrm{Ma})$ and late Miocene (12-Ma) phases of inversion of the coalfield. See text for discussior
Fig. 10 Vitrinite reflectance ( $R$ : $\% \max$ ) values for coal sample from the Rewanui Member of th: Late Cretaceous succession in th. Paparoa Trough (Bowman 1984 Boyd \& Lewis 1995). Note how the VR values increase system atically eastward across the basi? and reach a maximum near the $M$ : Davy Fault Zone. modelled through the thermal history framework provided by fission track analysis (Bray et al. 1992; Duddy et al. 1991). The integration of VR and fission track modelling allows tighter constraints on the unknown parts of the thermal history of the host rocks than would be possible to be obtained by using fission track modelling alone. Also, maximum temperatures experienced during burial can only be estimated or modelled from fission track data if the apatites have not been fully reset. As we have seen, over most of the Greymouth Coalfield the fission track parameters in apatite have been reset. In the reset zones the VR data have been modelled to establish the maximum temperatures, and the fission track data have been modelled to place limits on the timing of cooling during each of the uplift and erosion phases.

\section{Maximum paleotemperatures}

The permissible modelled range of maximum temperatures reached by the host rocks at $20 \mathrm{Ma}$ are listed in Table 4 .
Some samples were not modelled because of too few track length measurements. For samples in the exhumed partial annealing zone, the initial approach was to independent $y$ model the maximum temperatures based on VR and fissicin track data. In practice, for VR data the maximum temperature was judged by the match between the measured and predicted VR values; for fission tracks, it was based c? comparison of the measured and predicted mean track lengths, the shape of the track length distribution, and the fission track age. For many samples there was close agreement between the maximum paleotemperatures modelled through VR and fission tracks, in which case the temperature range adopted was weighted in favour of the VR estimate, and no predicted VR value is given in Table 4 , as it is the same value as the measured value. In cases whe the measured VR value appeared to be low by comparisci: with modelling of the fission track data, the fission trac: estimate of maximum temperature was adopted, and the corresponding predicted VR value(s) are given in Table 4 
Fig. 11 The distribution of maximum paleotemperature achieved in the late Oligocene by the Rewanui Member during burial in the Paparoa Trough. Paleotemperature estimates were made by forward modelling of fission track and vitrinite reflectance data, as described in the text.

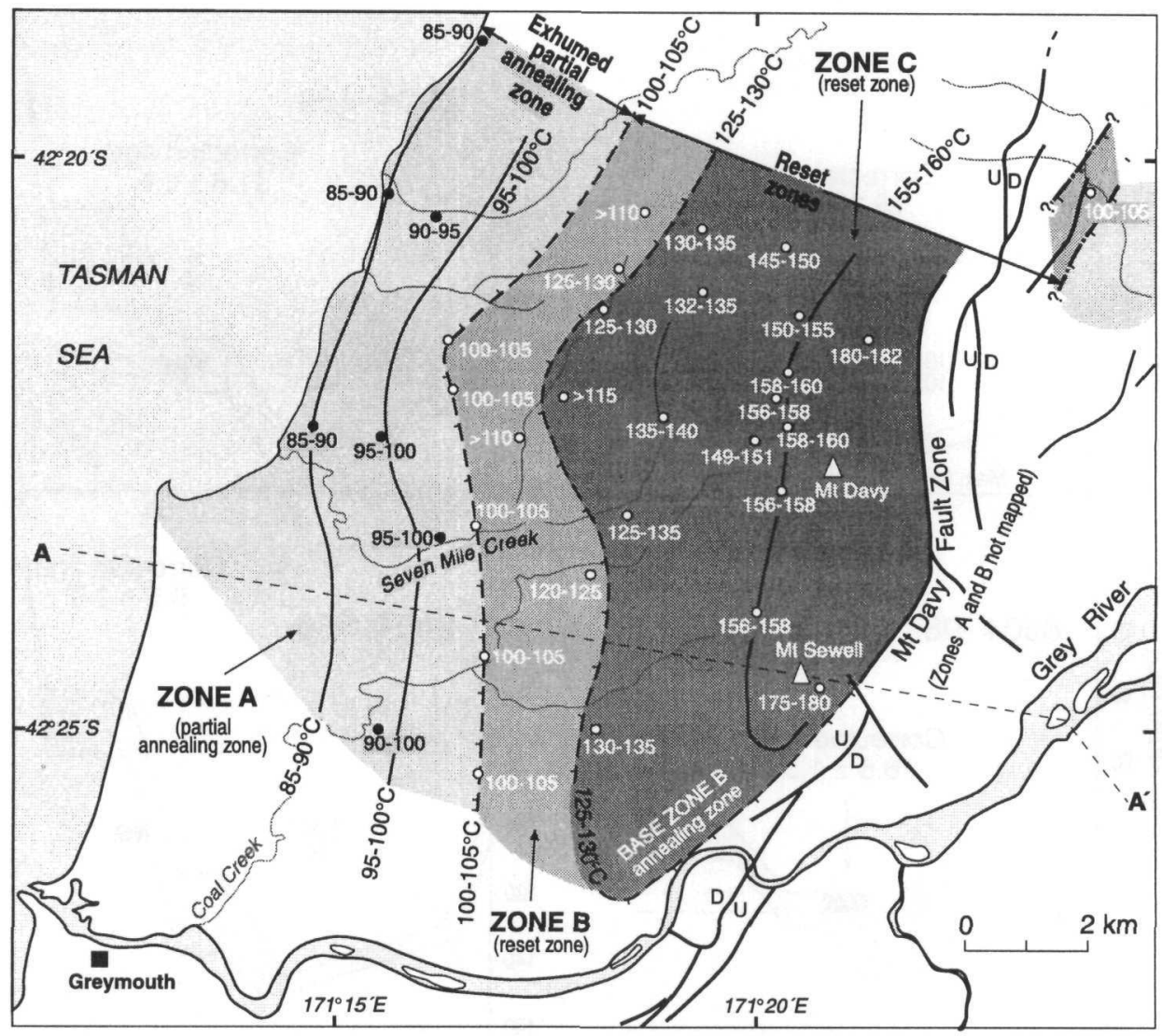

In the parts of the coalfield where the fission tracks in apatite have been reset, the maximum temperatures have been estimated from modelling of the VR data alone. For fission track sample sites for which there was not a measured VR value, one was interpolated from neighbouring sites, and this is indicated in Table 4 by underlining of these values. For a few sites in the deepest part of the coalfield VR values only are available - the maximum temperatures modelled for these sites are illustrated in Fig. 11.

Based on the earlier description of the fission track data, and the modelling of the maximum temperatures, the Greymouth Coalfield can be divided into three zones (Fig. 11). Zone A represents the exhumed partial annealing zone. The paleotemperature at the base of this zone reached 100 $105^{\circ} \mathrm{C}$, which reflects the fluorapatite composition of the apatites, and the slow rate of late Oligocene - early Miocene heating $\left(10-15^{\circ} \mathrm{C}, 32-20 \mathrm{Ma}\right)$. Paleo-isotherms corresponding to $85-90^{\circ}$ and $95-100^{\circ}$ are also mapped in Fig. 11. Zone B incorporates the succession in which apatites started to accumulate tracks after initial uplift-erosion started. In the central parts of the coalfield, the maximum temperatures in zone $\mathrm{B}$ ranged from $100-105^{\circ}$ to $125-130^{\circ} \mathrm{C}$. The rocks at or near the surface in zone $\mathrm{C}$ cooled below c. $105^{\circ} \mathrm{C}$ during the second uplift-erosion phase. Maximum paleotemperatures in this zone increased eastwards from $125-130^{\circ}$ to about $180^{\circ} \mathrm{C}$ across the coalfield to the Mt Davy Fault Zone. A mapped paleo-isotherm corresponding to $155-160^{\circ} \mathrm{C}$ in the centre of zone $\mathrm{C}$ is based exclusively on modelling of the VR data.

The distribution of paleotemperatures in Fig. 11 effectively defines the geometry of the Paparoa Trough at
Table 4 Current temperature, vitrinite reflectance, and modelled paleotemperature data.

\begin{tabular}{ccccr}
\hline Sample & $\begin{array}{c}\text { Current } \\
\text { temp }\left({ }^{\circ} \mathrm{C}\right)\end{array}$ & $\begin{array}{c}\text { Vitrinite } \\
\text { reflectance }\end{array}$ & $\begin{array}{c}\text { Predicted } \\
\text { VR }\end{array}$ & $\begin{array}{r}\text { Maximum } \\
\text { temp. }\left({ }^{\circ} \mathrm{C}\right)\end{array}$ \\
\hline $8904-0115$ & 0.56 & $0.56-0.60$ & $90-95$ & \\
-02 & 19 & 0.56 & $0.56-0.60$ & $90-95$ \\
-15 & 20 & $\underline{0.8}$ & - & $125-130$ \\
-22 & 27 & - & $\geq 0.63$ & $\geq 100$ \\
-25 & 36 & - & $\geq 0.66$ & $\geq 105$ \\
-28 & 18 & 1.13 & - & $150-155$ \\
-33 & 15 & $\underline{1.6}$ & - & $175-180$ \\
-42 & 15 & 0.52 & $0.57-0.62$ & $95-100$ \\
-44 & 15 & $\underline{0.83}$ & - & $125-135$ \\
-57 & 15 & 0.54 & - & $85-90$ \\
-98 & 20 & $\underline{0.76}$ & - & $120-125$ \\
-107 & 25 & 0.47 & $0.57-0.60$ & $95-100$ \\
-110 & 21 & - & $0.55-0.61$ & $90-100$ \\
-115 & 20 & - & - & $>110$ \\
-119 & 18 & 0.6 & $0.60-0.64$ & $100-105$ \\
-121 & 15 & - & $\sim 0.67$ & $>110$ \\
-123 & & 0.52 & - & $85-90$ \\
-124 & 25 & $\underline{0.85}$ & - & $130-135$ \\
-125 & 20 & 0.7 & $>0.7$ & $>115$ \\
-126 & 20 & 0.7 & $>0.7$ & $>115$ \\
-127 & 18 & 0.63 & - & $100-105$ \\
-128 & 20 & 0.63 & - & $100-105$ \\
-131 & 21 & 0.60 & $0.60-0.64$ & $100-105$ \\
-132 & 21 & 0.60 & $0.60-0.64$ & $100-105$ \\
-133 & 27 & - & $0.60-0.64$ & $100-105$ \\
-134 & 20 & 0.86 & - & $130-155$ \\
-135 & 20 & 1.13 & - & $150-155$ \\
-136 & 20 & 1.06 & - & $145-150$ \\
-139 & 20 & $\underline{0.8}$ & - & $125-130$ \\
\hline & & & &
\end{tabular}



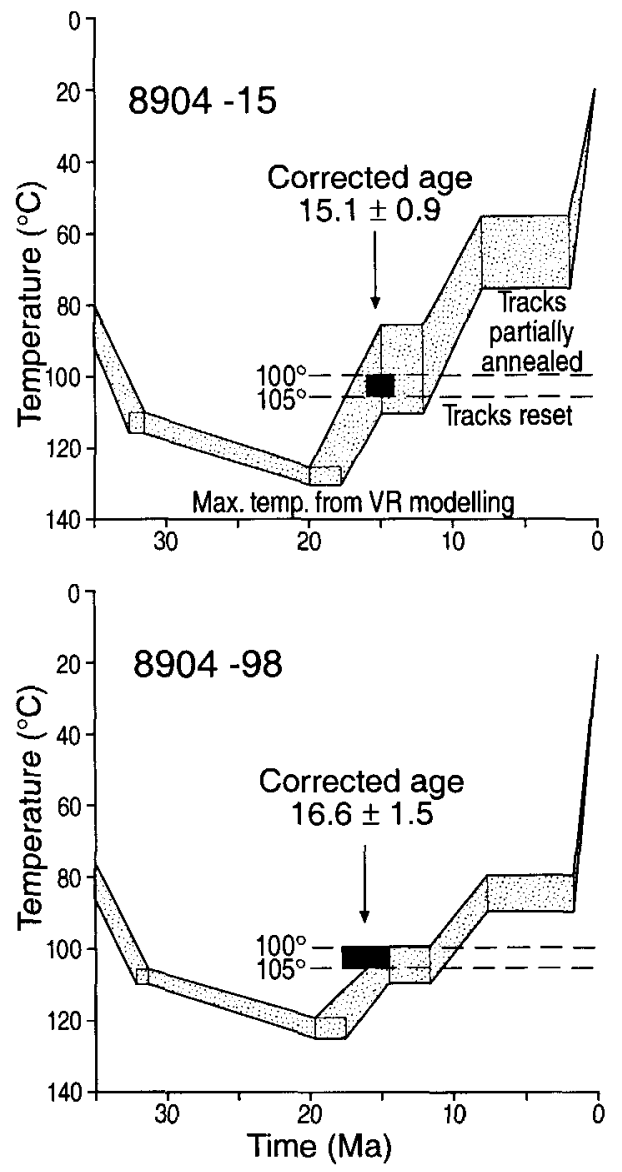

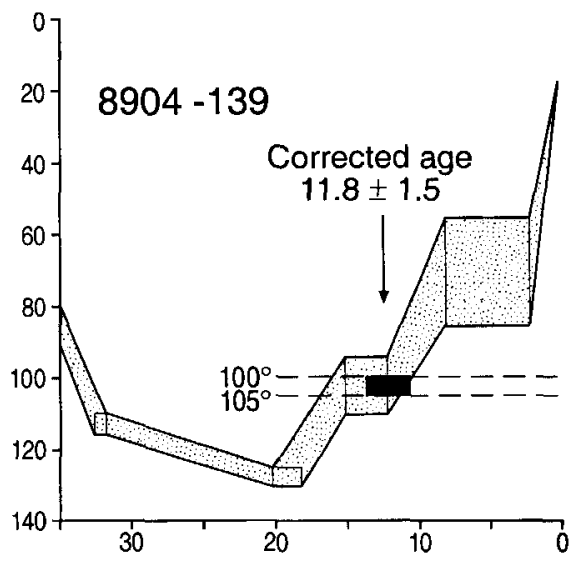

Fig. 12 Time-temperature plor: giving the possible heating an cooling paths for each of fou samples from the Greymout coalfield-Paparoa Trough. In all cases the late Oligocene max mum temperatures have bee: modelled from VR data, and th: timing of the cooling phases have been imposed from length corre: tion of all the reset fission trach. samples (Fig. 9). Also plotted (" solid black) are the field, indicating for the particulir samples the time-temperatuy space when the partial retention of tracks would have started.

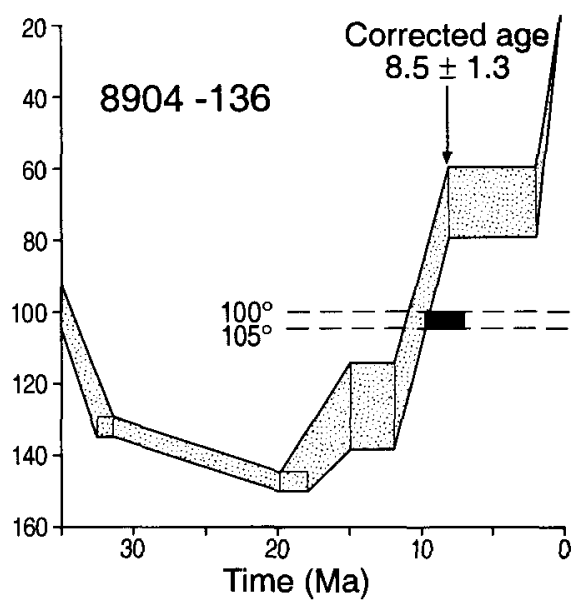

the point of its maximum subsidence: the paleo-isotherms are essentially structure contours, assuming no significant variations in the contemporary geothermal gradient. They correspond, however, to Rewanui Member, which lies up to a few hundred metres above basement. Despite the poor definition of paleo-isotherms along the eastern basin margin, the Paparoa Trough was clearly asymmetrical, which has always been known from the stratigraphic thicknesses preserved in the nose of the inversion structure (Gage 1952). Suggate (1959) reconstructed a similar basin geometry from an assessment of coal composition data interpreted in terms of rank, which increases rapidly eastwards across the coalfield to a maximum just west of the Mt Davy Fault Zone. From a petroleum generation perspective, coals in zone $A$ and part of zone B will be immature, whereas coals in zone $\mathrm{C}$ will have generated oil and gas.

\section{Cooling history}

Because the ages of the cooling phases are constrained by length correction of the reset fission track ages, and VR provides independent control on the maximum temperatures experienced by the host rocks, it is possible to model the amount of cooling that occurred during each of the cooling phases. Figure 12 illustrates the results of modelling the cooling paths for four samples. Samples $8904-15,98$, and 139 come from at or near the base of paleotemperatures in zone $\mathrm{B}$, meaning that cooling started during the first phase of uplift, but track retention started later. Modelling of these three samples should therefore give close to the maximum amount of cooling during the first uplift-erosion phase. A check on the validity of the modelling results is provided by the length-corrected age of each sample, which estimates the time since track accumulation started. This age, in combination with the temperature of the start of track retention $\left(100-105^{\circ} \mathrm{C}\right.$ for these fluorapatites), defines a field on time-temperature plots, marked in solid black for each sample in Fig. 12.

The corrected ages of samples $8904-15$ and 98 indicate that they cooled through $105-100^{\circ} \mathrm{C}$ at the end of uplift phase 1 , whereas this occurred at the start of uplift phase 2 fir sample 8904-139. Nevertheless, in all three cases, the amount of cooling coincides with the limits indicated ty the modelling, which amount to $15-40^{\circ} \mathrm{C}$ for phase one (8904-15 and 139) and $10-25^{\circ} \mathrm{C}$ for sample 8904-98, whic $h$ has a more southern location. The regional pattern suggests $20-30^{\circ}$ of cooling during phase one, being the difference between the paleotemperature maximum values for the bases of the zones A and B fossil partial annealing zone;, respectively. There are few constraints on the amount if cooling during phase one in the axis of the former basia. Sample $8904-33$ has an age of $10.2 \pm 2.6 \mathrm{Ma}$. No track lengths could be measured in this sample, but comparable samples have lengths of about $12.5 \mu \mathrm{m}$, which would give a length-corrected age of c. $12 \mathrm{Ma}$. This age would allow track accumulation to start at the beginning of the second uplift-erosion phase, meaning that the sample host rocks cooled to $110-105^{\circ} \mathrm{C}$ during the first uplift phase, implying $65-75^{\circ}$ of cooling at that time.

The modelling of samples 8904-15 and 139 suggests between $10^{\circ}$ and $55^{\circ}$ of cooling during the second phase of 
uplift-erosion, and between $10^{\circ}$ and $30^{\circ}$ for sample 8904 98. Based on the time-temperature fields defined by the corrected fission track ages, the maximum possible cooling is reduced by $5^{\circ} \mathrm{C}$. This leaves a minimum of $35^{\circ}$ of cooling during the Quaternary for samples 8904-15 and 139, and $60^{\circ} \mathrm{C}$ for sample $8904-98$. As the topography rises to 1000 $\mathrm{m}$ in the northern part of the field area, and most of this probably developed during the Quaternary (Nathan et al. 1986), there was at least $30^{\circ} \mathrm{C}$ of cooling at this time, consistent with the modelling results.

The cooling history of sample 8904-136 from zone C was modelled with limited success. Figure 12 shows the possible cooling paths, given that the timing of cooling was imposed on the modelling. From the corrected age, the apatites in this sample started to retain tracks during the second uplift and erosion phase. The modelling implies 10 $35^{\circ} \mathrm{C}$ of cooling during phase $1,35-80^{\circ} \mathrm{C}$ during phase 2 , and $40^{\circ} \mathrm{C}$ during the Quaternary, but the fission track data are also almost consistent with uniform cooling from $20 \mathrm{Ma}$.

\section{Amounts and rates of inversion}

The amount of rock uplift over the inversion structure can be calculated assuming that the present geothermal gradient in sedimentary section in the region $\left(29^{\circ} \mathrm{C} / \mathrm{km}\right)$ has been the same for the past $20-30 \mathrm{~m}$.y. On the cross section through the field area (Fig. 3) has been added an estimate of the total amount of sedimentary section that formerly overlaid the Rewanui Member in the Paparoa Trough. This reduces from about $1200 \mathrm{~m}$ beneath the modern coastline to about $6300 \mathrm{~m}$ adjacent to the Mt Davy Fault Zone, which everywhere is more than the amounts illustrated by Nathan (1978). The uplift west of the range front fault was therefore about twice the maximum amount of subsidence in the Grey Valley Trough.

Based on the modelling results, the amounts and rates of rock uplift for each of the three Neogene uplift-erosion phases are listed in Table 5. The data are more or less consistent with each inversion having been of equivalent magnitude, although the rates of inversion have increased with each successive phase because the duration of each of the phases has progressively decreased.

\section{Stick-slip behaviour of the fault zone during inversion}

Each of the two Miocene uplift-erosion phases involving the Brunner-Mt Davy Anticline identified directly from fission track data, coincide broadly with unconformities within the stratigraphic section of the western limb of the Grey Valley Syncline (Fig. 13B), but there are important offsets. The start of uplift of the first phase, at $20 \mathrm{Ma}$, coincides with the biostratigraphically constrained unconformity, but uplift west of the range front fault continued until $15 \mathrm{Ma}$, about $2 \mathrm{~m}$.y. after marine sedimentation resumed in the basin adjacent to the range front. The same pattern is repeated in the late Miocene. Renewed uplift started at $12 \mathrm{Ma}$ and continued until about $7 \mathrm{Ma}$. The biostratigraphic age of the Rotokohu Coal Measures is not precisely known, but the age of its base along the range front is at least as old as $9 \mathrm{Ma}$ (lower Tongaporatuan, Nathan 1978), implying a 2 m.y. long interval when uplift to the west of the fault zone coincided with sedimentation immediately to the east of it.

The apparent mismatch in timing of uplift and unconformity development can be reconciled in the context of a fault zone that underwent repeated cycles of coupling and uncoupling, that is, stick-slip behaviour, in response to regional cycles of compression and crustal shortening driven by changes in the relative motion of the Australia and Pacific plates. When the study area first became compressive, both sides of the normal fault zone that bounded the Paparoa Trough would have been coupled, resulting in upward motion in an absolute frame on both sides of the fault, causing erosion that contributed to unconformity development along the eastern margin. With continued early Miocene shortening, the fault zone would have decoupled (slipped), allowing the uplifted block to freely overthrust the basement to the east. The loading that resulted would have depressed the area immediately east of the fault zone below sea level, thereby generating accommodation, which permitted marine Stillwater Mudstone to accumulate, while uplift and erosion continued to the west of the developing range front fault. It is envisaged that this sequence of structural events was repeated in the late Miocene (Fig. 13B) and possibly also in the late Pliocene-Pleistocene.

Between the axis and westernmost margin of the Grey Valley Syncline, the Stillwater Mudstone was thinned by erosion from c. 1.7-c. $0.5 \mathrm{~km}$ thick during the early part of the second uplift-erosion phase. This corresponds to about half of the mid to late Miocene uplift immediately west of the Mt Davy Fault Zone (Table 5). This may suggest that the duration of coupling of the fault zone was about half of the total interval of uplift in the main zone of uplift. There are insufficient data about the stratigraphy along the eastern margin of the syncline at present to undertake these types of calculations for the other phases of uplift.

\section{STRUCTURAL EVOLUTION IN A REGIONAL TECTONIC CONTEXT}

The Brunner-Mt Davy Anticline-Grey Valley Syncline pair occur along the central-southern part of Laird's (1968) Paparoa Tectonic Zone. This zone has been considered to extend for about $200 \mathrm{~km}$ as a more-or-less continuous structure from the Alpine Fault near Hokitika River to Kongahu Point, obliquely crossing the Paparoa Range. The Buller Coalfield lies at the northern end of this tectonic zone, and it has long been known that the sense of displacement on the Kongahu Fault Zone, which lies between the Paleogene and Neogene basins, is opposite to that in the Greymouth area (Suggate 1959, Laird 1968, Nathan et al. 1986) (Fig. 13A). In Laird's (1968) concept of the Paparoa Tectonic Zone this was explained by scissors movement on

Table 5 Amounts and rates of rock uplift in Greymouth Coalfield.

\begin{tabular}{llclcc}
\hline & \multicolumn{2}{c}{ Inversion axis $^{1}$} & & \multicolumn{2}{c}{ Centre of coalfield ${ }^{2}$} \\
\cline { 2 - 3 } \cline { 5 - 6 } $\begin{array}{l}\text { Interval } \\
\text { (Ma) }\end{array}$ & $\begin{array}{c}\text { Amount } \\
(\mathrm{km})\end{array}$ & $\begin{array}{c}\text { Rate } \\
(\mathrm{mm} / \mathrm{yr})\end{array}$ & & $\begin{array}{c}\text { Amount } \\
(\mathrm{km})\end{array}$ & $\begin{array}{c}\text { Rate } \\
(\mathrm{mm} / \mathrm{yr})\end{array}$ \\
\hline $20-15$ & $2.2-2.6$ & $0.44-0.52$ & & $0.7-1.0$ & $0.14-0.21$ \\
$12-8$ & $2.2-2.4^{*}$ & $0.56-0.60^{*}$ & & $0.4-0.7$ & $0.09-0.43$ \\
$2-0$ & $c .1 .4^{\dagger}$ & 0.69 & & $1.2-2.1$ & $0.61-1.04$ \\
\hline
\end{tabular}

${ }^{1}$ Corresponding to location of Mt Sewell.

${ }^{2}$ Position corresponding to eastern margin of zone B in Fig. 11.

*Range of values assume $40^{\circ} \mathrm{C}$ of cooling during Quaternary.

${ }^{\dagger}$ Assumption based on development of present topography during past $2 \mathrm{~m} . \mathrm{y}$. 


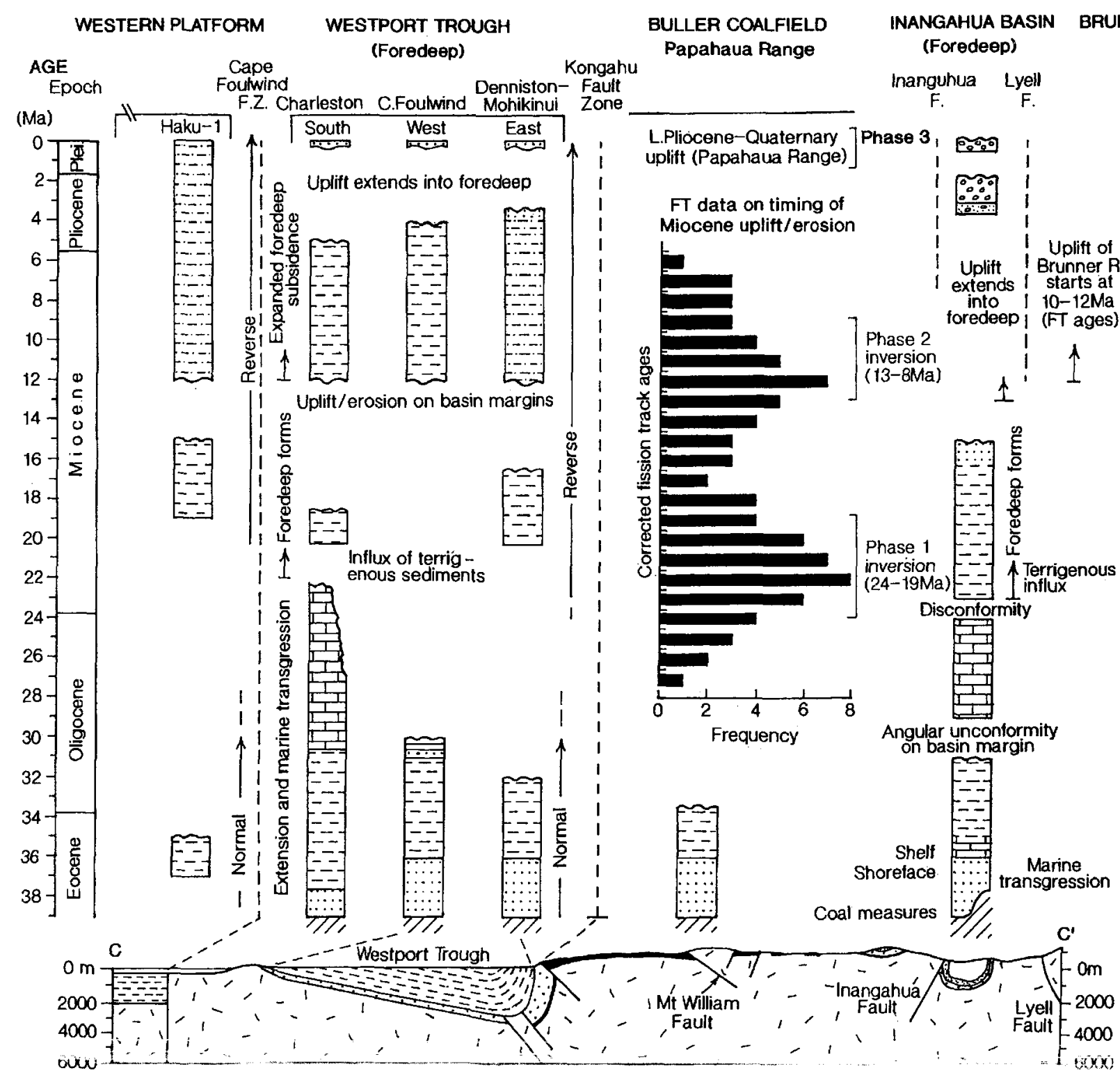

Stages
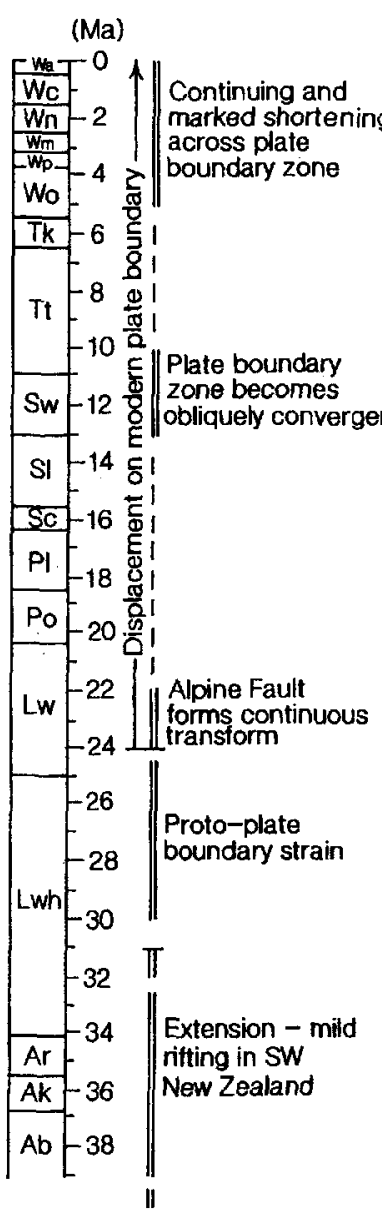

A
TECTONIC Fig. 13 Time-stratigraphic NTERPRETATION synthesis for the Buller Coalfield region (in A), modified from Kamp et al. (1996, Fig. 12) and Creyn al (196, Fig. (2) region (in B), showing the timing of inversion from apatite fission track data in relation to the distribution of sedimentary section and unconformities in the adjacent foredeeps. In $\mathbf{A}$, for Buller the region comprises five structural blocks bounded by mijor faults, the sense of five strajor faults, the sense of displacement on several of them changing between the late Oligocene and early Miocene. In $\mathbf{B}$, for Greymouth Coalfield there are three structura domains separated by the Cape Foulwind Fault Zone and the Mt Davy Fault Zone. Note in both $\mathbf{A}$ and $\mathbf{B}$ how the start of Phase 1 uplift and erosion in the inverted Paleogene-(Late Cretaceous) coal basin corresponds to uplift and erosion of section in the Neogene basins (foredeeps), whereas the later part of this inversion phase coincides with subsidence and sedimentation in these basins. This pattern is also evident for the late Miocene phase of inversion. This is explained by a model of stick-slip behaviou on the major fault zones. See text for discussion. New Zealand Stage abbreviations: $\mathrm{Ab}$, Bortonian; Ak, Kaiatan; Ar Runangan; Lwh, Whaingaroan; Lw, Waitakian; Po, Otaian; Pl, Altonian; Sc, Clifdenian; S1, Lillburnian; Sw, Waiauan; Tt,

unntinued on n 463 
TECTONIC INTERPRETATION
C. Foulwind

AGE
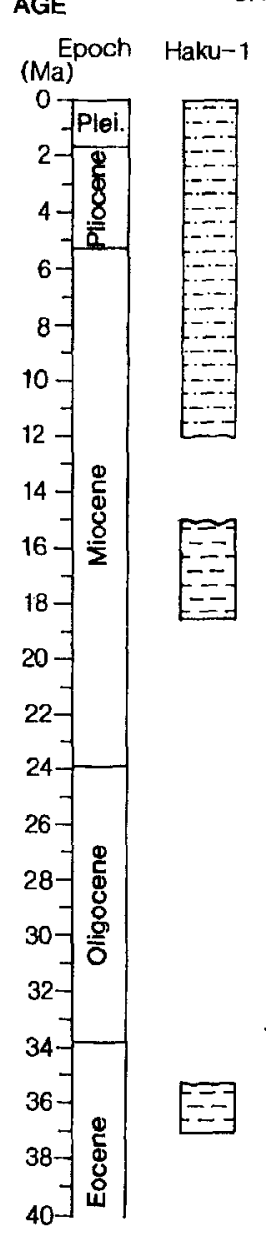

F.Z. Grey River Gorge-Ponth
Elizabeth

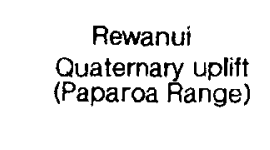
Mt Davy Moonlight Ck Notown-1 hole

N.Z. Stage

Angular

inge Uplift/erosion exterids into foredeep FT data on timing of Miocene

Uplift /erosion to the west

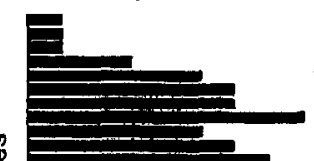
$7 \begin{array}{r}1 \\ 1\end{array}$

: $\because$ Old Man Gp $\therefore$ ㄱ. 2 Rotokohu Phase 2
inversion

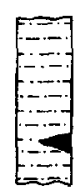

8

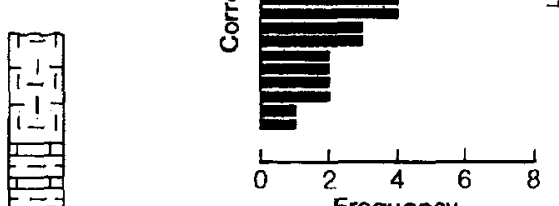
$\int(12-71$

Angular unconformity

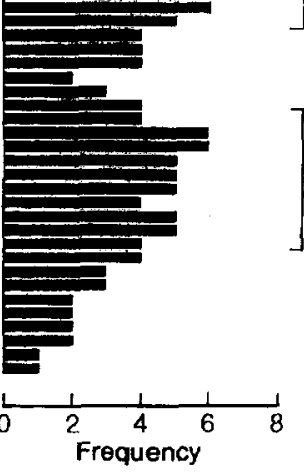

Uplift/erosion on

in margin $\begin{array}{ccc}1 & \text { Stillwater } \\ \text { 1 } & \text { Mudstone }\end{array}$ inversion

(20-15Ma) Angular
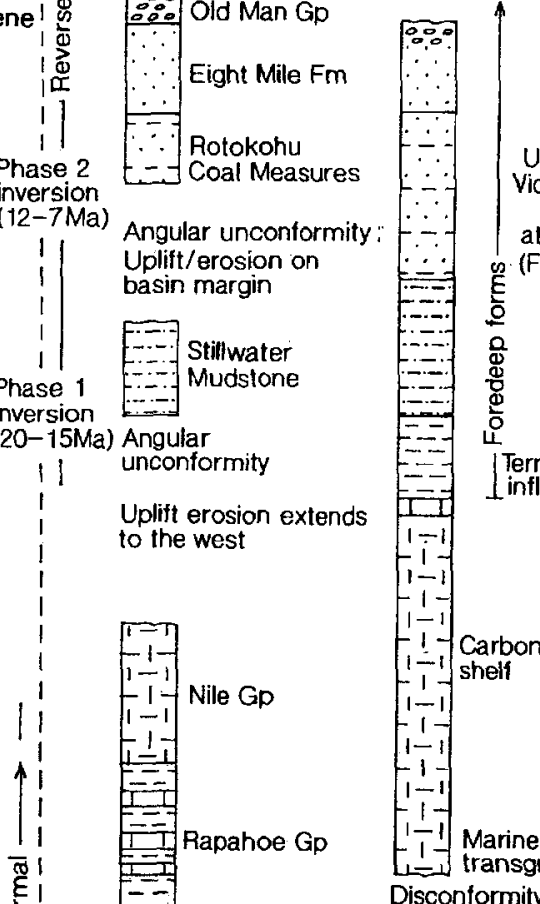

Uplift of

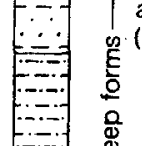

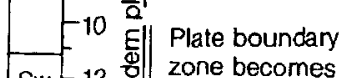

$\stackrel{(\mathrm{Ma})}{\mathrm{Wa}_{\mathrm{a}}-{ }_{-2}^{-}} \uparrow \| \begin{aligned} & \text { Continuing and } \\ & \text { marked shortening }\end{aligned}$

Wm- across plate

Wo- 4 त्ञा boundary zone

TK-6

1

(Sw-12 obliquely convergen

$\therefore \quad 1 \quad$ sif-14

$=0.0$

-7
$1-1$
$i-1$

Terrig

$\mathrm{Sc}-16$ 帝

PI 18 嵌

influx

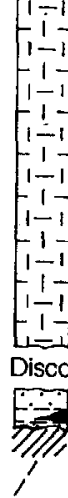

\section{-22 Alpine Fault \\ Fault \\ Lw 1 .l transform}

- 1 Proto modern

Carbonate

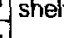

$1-1$

$1-1$

Disconformity

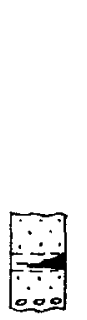

Underlain by Mawheranui Gp.

WISt,

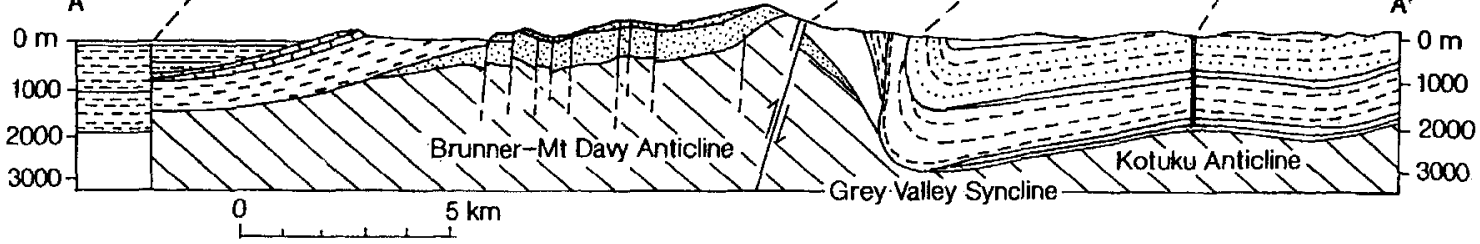

B

Tongaporutuan, Tk, Kapitean; Wo, Opoitian; Wp, Waipipian Wm, Mangapanian; Wn, Nukumaruan W Wc Castlecliffian; Wa Haweran. Lithology symbols: brickwork pattern, limestone dots, sandstone; horizontal dashes, siltstone; horizontal dashes with dots, sandy siltstone; circles, conglomerate. Basement in A (mainly granite) indicated in cross section by randomly oriented marks, and in B (mainly sedimentary) by sloping lines. Position of Haku1 exploration hole shown on Fig. 1. 


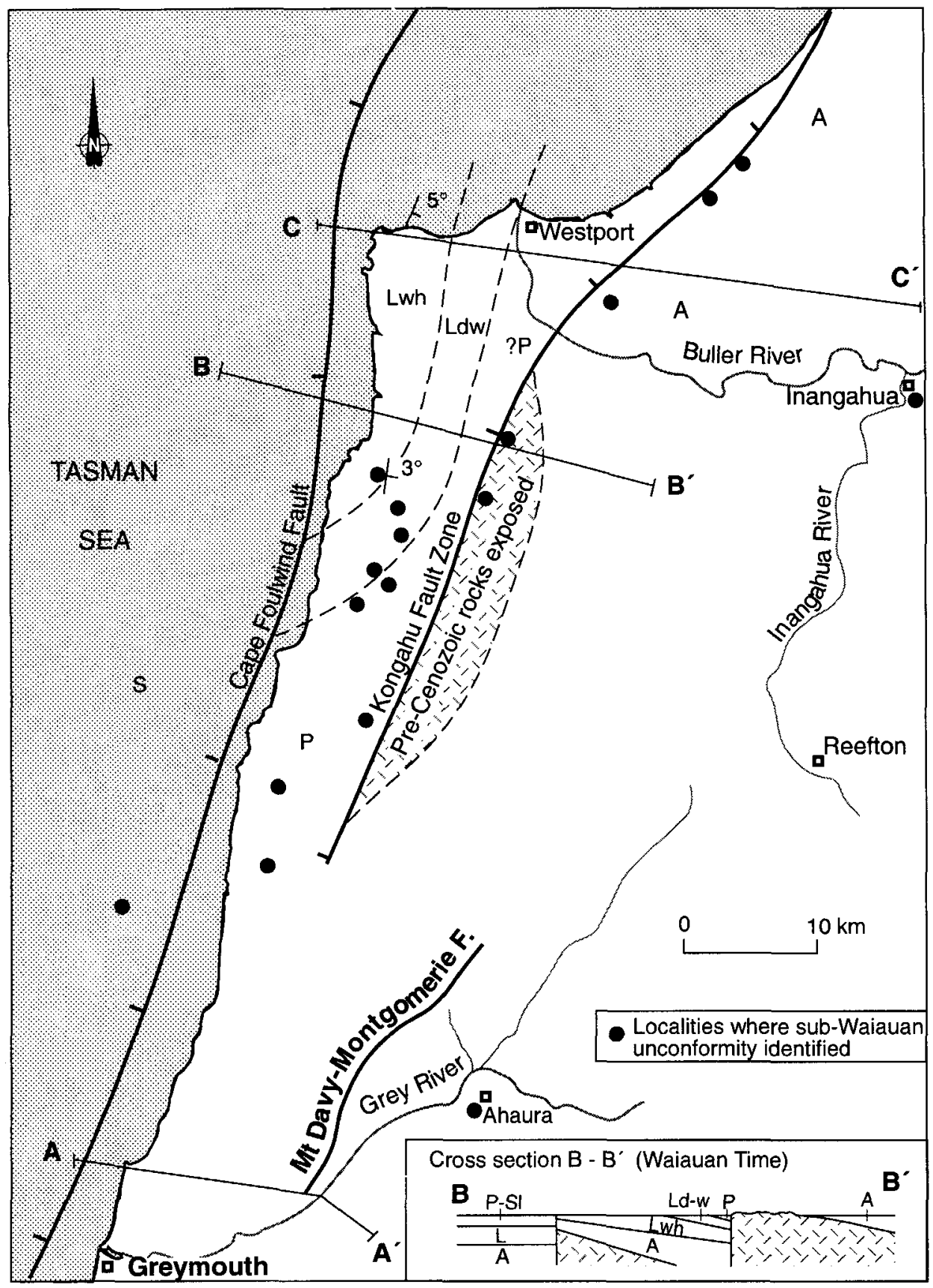

Fig. 14 Paleogeological map for northern Westland and Bulle: redrawn from Nathan et al. (1986. fig. 3.28) showing the possible? early Waiauan (late Miocene) disposition of the Kongahu and Mt Davy-Montgomerie Fault Zones, and the age of sediment: underlying the sub-Waiauar unconformity. A-A' is the line of cross section through the Greymouth Coalfield shown ir Fig. 3 and $13 B$, and $C-C^{\prime}$ is th. line of the Buller Coalfield cros section shown in Fig. 13A. Cros: section $B-B^{\prime}$ is a mid-Waiaua palinspastic restoration from Nathan et al. (1986, fig. 3.28)

the continuous fault zone, with the pivot located near $\mathrm{Mt}$ Anderson. An implication of this structural model is that the timing of the Neogene inversion phases ought to be coincident between the Buller and Greymouth Coalfields. This appeared to be satisfied by the stratigraphic data available to Laird at the time. The timing of inversion of the Paleogene basins was inferred then from the stratigraphic section in the Neogene foredeeps and not dated from the zones of uplift themselves. Work subsequent to Laird (1968), and in particular that of Nathan et al. (1986, Fig. 3.28), has questioned the reality of a continuous Cenozoic tectonic zone through the Paparoa Range. In a paleogeological map, redrawn in Fig. 14, they suggest that the Kongahu Fault Zone was not linked directly to the Mt Davy-Montgomerie Fault Zone in the Greymouth area. Although not shown by Nathan et al. (1986) or on Fig. 14, it is even possible that the tw: fault zones overlap in their latitudinal extents. This type of structural arrangement would more easily allow fo." independent timing of displacement on separate northern an $\mathrm{k}$ southern fault zones.

The fission track data suggest an earlier (24-19 Ma) initiation and termination of uplift during the early Miocere. phase of inversion (Fig. 13A) in the Buller compared with the Greymouth coalfields $(20-15 \mathrm{Ma})$. The data allow for minimal overlap during the first phase of the inversic n histories. The earlier inversion in the Buller area appears ti be supported by the earlier influx of terrigenous sediments in the Inangahua Basin (mid-Waitakian) compared with the Grey Valley Trough (Otaian, Nathan et al. 1986) (Fig. 13). The fission track timing of the beginning of uplift in the 
Buller Coalfield (c. $24 \mathrm{Ma}$ ) coincides with other radiometric evidence for the start of horizontal offset on the Alpine Fault (Cooper et al. 1987). The simplified palinspastic cross section B-B' shown in Fig. 14 for early Waiauan time (c. 12.5 $\mathrm{Ma}$ ) shows another feature suggesting that reverse movement also occurred on the Cape Foulwind Fault Zone during phase one (24-19 Ma), as the late Eocene-Oligocene succession between it and the Kongahu Fault Zone was tilted and eroded. The amount of erosion decreases to the south (Fig. 14), and from this it is inferred that the degree of shortening was therefore more widespread and substantial in the Buller region compared with the Greymouth region.

The earlier timing of uplift/erosion and terrigenous influx, and the extent and degree of shortening in the Buller area compared with the Greymouth area, taken together suggest that the Buller region lay closer to the contemporary transform plate boundary (Alpine Fault), and hence the source of compression and crustal shortening at 23-24 Ma. Some $4 \mathrm{~m}$.y. or so after dextral displacement started on the Alpine Fault Zone, the Greymouth Coalfield region became influenced by compression originating at the Alpine Fault Zone. A southward migration in the timing of the initiation of uplift, identified here between Buller and Greymouth Coalfields, is a pattern described previously in South Westland between the Hohonu Range and Cape Jackson but for a younger interval. There the timing of uplift/erosion ranges between $12 \mathrm{Ma}$ in the north and $2 \mathrm{Ma}$ in the South (Kamp et al. 1992). The opposite direction of younging has been established east of the Alpine Fault in the Southern Alps mountain range (Kamp et al. 1989; Kamp \& Tippett 1993; Tippett \& Kamp 1993). This is explained by the progressive juxtaposing of continental basement either side of the Alpine Fault in response to continuing horizontal offset on the transform.

The fission track estimates of the timing of the late Miocene phase of uplift/erosion and shortening across the Buller and Greymouth Coalfields are the same for both regions (12/13-7/8 Ma, Fig. 13). This suggests that by this time both areas lay northwest of an Alpine Fault juxtaposing continental basement, and that the late Miocene inversion was more extensive than that during the early Miocene. This is the interval when the Inangahua Fault formed, with uplift of the eastern flank of the Buller Coalfield basin, which overthrust (eastwards) the upper Eocene to middle Miocene succession that had accumulated within it and the younger lnangahua Basin (Fig. 13A) (Kamp et al. 1996). The more widespread late Miocene inversion is also reflected in marked shallowing of the southern part of the Grey Valley Trough, and a transition from marine (Stillwater Mudstone) to nonmarine (Rotokohu Coal Measures) facies in central parts of the trough (Nathan et al. 1986) (Fig. 13B).

The late Miocene phase of inversion has also been identified more widely in western South Island basement now at the surface (Greenland Group and Fraser Complex) adjacent to the Alpine Fault in South Westland, which cooled substantially via uplift and erosion during the interval 12-8 Ma (White \& Green 1986; Kamp et al. 1992). The sedimentary succession intersected in the hydrocarbon hole Fresne-1 in southern Taranaki Basin was inverted by reverse movement on a previously normal fault during the interval 12-8 Ma (Kamp \& Green 1990). The Murchison Basin has been shown from modelling of fission track data to have been inverted c. 12-9 Ma (Gibson et al. 1996).

\section{SUMMARY}

This paper reports information about the maximum temperatures experienced by Late Cretaceous and mid Eocene strata preserved in the Greymouth Coalfield, the time when cooling from these temperatures started and, for some sample horizons, the style of cooling. This information has been derived by the simultaneous modelling of fission track and vitrinite reflectance data in a forward modelling approach. Two discrete phases of cooling achieved through uplift and erosion are identified, one during the early Miocene (20-15 m.y. BP) and another during the late Miocene (12-7 m.y. BP). A third phase occurred during the Quaternary, and has exhumed the sedimentary rocks carrying the records of the earlier events.

This information has been integrated with structural and stratigraphic data available for the Coalfield and adjacent areas (Nathan 1978), in particular the age and duration of strata preserved between tilted unconformities within the western limb of the Grey Valley Syncline, which is common with the eastern limb of the Brunner-Mt Davy Anticline. This reveals that the middle Miocene Stillwater Mudstone and the late Miocene Rotokohu Coal Measures overlap in age with the late early to middle Miocene and late Miocene phases of inversion of the coalfield basin underlying the anticline structure. The inversion structure and basin margin stratigraphy are reconciled in a stick-slip model of fault behaviour involving repeated coupling and uncoupling of the fault zone in response to regional cycles of compression and crustal shortening driven by relative motion at the Australia-Pacific plate boundary. In the early part of a compressive phase the fault zone is locked, and uplift and erosion extends into the basin margin; in the later part the fault unlocks and the inverted succession overthrusts the adjacent basin, loading it tectonically, as well as with sediment, thereby generating the foredeep, while uplift and erosion continues for c. $2 \mathrm{~m} . \mathrm{y}$. west of the fault zone and over the antiform.

The Neogene evolution of the Brunner-Mt Davy Anticline and Grey Valley Syncline is compared with the evolution of a similar structural pair across the Kongahu Fault Zone (Kamp et al. 1996), involving the Buller Coalfield and Westport Trough. What emerges is that the early Miocene phase of inversion of the Buller Coalfield occurred about $4 \mathrm{~m}$.y. earlier than the inversion in the Greymouth Coalfield. This reflects the more southern and distant location of the Greymouth area from the loci of contemporary earliest Miocene plate boundary interaction. An implication is that the fault zone along the eastern range front involving the Greymouth Coalfield is not continuous with the Kongahu Fault Zone along the western range front of the Buller Coalfield. The late Miocene phase of inversion is coincident in both coalfields, and reflects widespread uplift in northern Westland and Buller as shown also by earlier fission track studies.

\section{ACKNOWLEDGMENTS}

The directors of Geotrack International Pty Ltd are thanked for providing access to apatite fission track modelling software. $M$. Cave is thanked for assistance in setting up this project, and $\mathrm{N}$. Newman for supplying samples from the Ministry of Commerce Core Store. We thank Frank Bailey and Betty-Ann Kamp for the cartography, Elaine Norton for typing the manuscript, and 
S. Nathan, P. Fitzgerald, and an anonymous reviewer for helpful comments on the manuscript. This project was funded by the N.Z. Foundation for Research Science and Technology (UOW507) and the Market Information and Analysis section of the Energy and Resources Division, New Zealand Ministry of Commerce.

\section{REFERENCES}

Armstrong, P. A.; Chapman, D. S.; Funnell, R. N.; Allis, R. G.; Kamp, P. J. J. 1996: Thermal modelling and hydrocarbon generation in an active-margin basin: The Taranaki Basin, New Zealand. American Association of Petroleum Geologists Bulletin 80: 1216-1241.

Bowman, R. G. ed. 1984: Greymouth Coalfield report. New Zealand Coal Resources Survey, prepared for Mines Division, Ministry of Energy, by Lime and Marble Limited.

Boyd, R. J.; Lewis, D. W. L. 1995: Sandstone diagenesis related to varying burial depth and temperature in Greymouth Coalfield, South Island, New Zealand. New Zealand Journal of Geology and Geophysics 38: 333-348.

Bray, R. J.; Green, P. F.; Duddy, I. R. 1992: Thermal history reconstruction using apatite fission track analysis and vitrinite reflectance: a case study from the U.K. East Midlands and southern North Sea. In: Hardman, R. F. P. ed. Exploration Britain: Geological insights for the next decade. Geological Society, London, Special Publication 67: 3-25.

Burnham, A. K.; Sweeney, J. J. 1989: A chemical kinetic model of vitrinite reflectance maturation. Geochimica et Cosmochimica Acta 53: 2649-2657.

Cooper, A. F.; Barreiro, B. A.; Kimbrough, D. L.; Mattinson, J. M. 1987: Lamprophyre dike intrusion and age of the Alpine Fault, New Zealand. Geology 15: 941-944.

Duddy, I. R.; Green, P. F.; Laslett, G. M. 1988: Thermal annealing of fission tracks in apatite 3. Variable temperature behaviour. Chemical Geology 73: 25-38.

Duddy, I. R.; Green, P. F.; Hegarty, K. A.; Bray, R. J. 1991: Reconstruction of thermal history in basin modelling using apatite fission track analysis. Offshore Australia Conference Proceedings 1: 49-61.

Gage, M. 1952: Greymouth Coalfield. New Zealand Geological Survey Bulletin 45.

Galbraith, R. F. 1981: On statistical methods of fission track counts. Mathematical Geology 13: 471-478

Galbraith, R. F.; Green, P. F. 1990: Estimating the component ages of a finite mixture. Nuclear Tracks and Radiation Measurements 17: 197-206.

Gibson, H. J.; Green, P. F.; Wilson, C. J. L. 1996: Thermal history reconstruction in and around the Murchison Basin: implications for hydrocarbon prospectivity. $1996 \mathrm{New}$ Zealand Petroleum Conference Proceedings 1: 76-85. Wellington, Ministry of Commerce.

Gleadow, A. J. W.; Fitzgerald, P. G. 1987: Uplift history and structure of the Transantarctic Mountains: new evidence from fission track dating of basement apatites in the Dry Valleys area, Southern Victoria Land. Earth and Planetary Science Letters 82: 1-14.

Gleadow, A. J. W.; Duddy, I. R.; Lovering, J. F. 1983: Fission track analysis: a new tool for the evaluation of thermal histories and hydrocarbon potential. APEA Journal 23: 93-102.

Green, P. F. 1981: A new look at statistics in fission track dating. Nuclear Tracks 5: 77-86.

Green, P. F. 1985: A comparison of zeta calibration baselines in zircon, sphene and apatite. Chemical Geology (Isotope Geoscience Section) 58: 1-22.
Green, P. F. 1988: The relationship between track shortening and fission track age reduction in apatite; combined influence: of inherent instability, annealing anisotropy, length bia: and system calibration. Earth and Planetary Scienc Letters 89: 335-352.

Green, P. F.; Duddy, I. R.; Gleadow, A. J. W.; Tingate, P. R.; Lasletı G. M. 1986: Thermal annealing of fission tracks in apatit: 1. A qualitative description. Chemical Geology (Isotop: Geoscience Section) 59: 237-253.

Green, P. F.; Duddy, I. R.; Laslett, G. M.; Hegarty, K. A.; Gleadow A. J. W.; Lovering, J. F. 1989a: Thermal annealing ct fission tracks in apatite 4. Quantitative modellin techniques and extension to geological timescales Chemical Geology (Isotope Geoscience Section) is 155-182.

Green, P. F.; Duddy, I. R.; Gleadow, A. J. W.; Lovering, J. F. 1989t, Apatite fission track analysis as a paleotemperature indicator for hydrocarbon exploration. In: Naesar, N. D McCulloch, T. ed. Thermal history of sedimentary basin. - methods and case histories. New York, Springer-Verlag Pp. 181-195.

Hurford, A. J. 1986: Cooling and uplift patterns in the Lepontin: Alps, South Central Switzerland, and an age of vertical movement on the Insubric fault line. Contributions $t$, Mineralogy and Petrology 92: 413-427.

Hurford, A. J.; Green, P. F. 1982: A user's guide to fission trach dating calibration. Earth and Planetary Science Letters 5 , 343-354.

Kamp, P. J. J. 1986a: Late Cretaceous-Cenozoic tectorii development of the southwest Pacific region Tectonophysics 121: 225-251.

Kamp, P. J. J. 1986b: The mid-Cenozoic Challenger Rift Systen of western New Zealand and its implications for the age of Alpine Fault inception. Geological Society of Americ Bulletin 97: 255-281.

Kamp, P. J. J.; Green, P. F. 1990: Thermal and tectonic history o: selected Taranaki Basin (New Zealand) wells assessed b: apatite fission track analysis. Bulletin America, Association of Petroleum Geologists 74: 1401-1419.

Kamp, P. J. J. 1991: Late Oligocene Pacific-wide tectonic event Terra Nova 3: 65-69.

Kamp, P. J. J.; Green, P. F.; White, S. H. 1989: Fission track analys: reveals character of collisional tectonics in New Zealans Tectonics 8: 169-195.

Kamp, P. J. J.; Green, P. F.; Tippett, J. M. 1992: Tectoni. architecture of the mountain front-foreland basis transition, South Island, New Zealand, assessed by fission track analysis. Tectonics 11: 98-113.

Kamp, P. J. J.; Tippett, J. M. 1993: Dynamics of Pacific plate crust in the South Island (New Zealand) zone of obliqus continent-continent collision. Journal of Geophysica! Research 98: 16105-16118.

Kamp, P. J. J.; Webster, K. S.; Nathan, S. 1996: Thermal histor: analysis by integrated modelling of apatite fission traci and vitrinite reflectance data: application to an inverter basin (Buller Coalfield, New Zealand). Basin Research \& 383-402.

Laird, M. G. 1968: The Paparoa Tectonic Zone. New Zealan. Journal of Geology and Geophysics 11: 435 454.

Laslett, G. M.; Kendall, W. S.; Gleadow, A. J. W.; Duddy, I. F: 1982: Bias in the measurement of fission track lengtl distributions. Nuclear Tracks 6: 79-85

Laslett, G. M.; Green, P. F.; Duddy, I. R.; Gleadow, A. J. W. 198? Thermal annealing of fission tracks in apatite $2: A$ quantitative analysis: Chemical Geology (Isotop. Geoscience Section) 65: 1-13.

Nathan, S. 1978: Sheet 44-Greymouth. Geological map of Ner. Zealand 1:63 360. Wellington, New Zealand. Departmen of Scientific and Industrial Research, 
Nathan, S.; Anderson, H. J.; Cook, R. A.; Herzer, R. H.; Hoskins, R. H.; Raine, J. I.; Smale, D. 1986: Cretaceous and Cenozoic sedimentary basins of the West Coast Region, South Island, New Zealand. New Zealand Geological Survey Basin Studies Report $l$.

Newman, J; Newman, N. 1992: Tectonic and paleoenvironmental controls on the distribution and properties of Upper Cretaceous coals on the West Coast of the South Island, New Zealand. In: McCabe, P. J.; Parrish, J. T. ed. Controls on the distribution and quality of Cretaceous Coals. Geological Society of America Special Paper 267. Boulder, Colorado. Pp. 347-368.

Vorris, R. J.; Carter, R. M.; Turnbull, I. M. 1978: Cainozoic sedimentation in basins adjacent to a major continental transform boundary in southern New Zealand. Journal of Geological Society London 135: 191-205.
Pilaar, W. F. H.; Wakefield, L. L. 1978: Hydrocarbon generation in the Taranaki Basin, New Zealand. The American Association of Petroleum Geologists Memoir 15: 405- 423.

Smale, D. 1978: Petrology of some Mauheranui Group rocks. New Zealand Geological Survey report G25.

Suggate, R. P. 1959: New Zealand coals. New Zealand Department of Scientific and Industrial Research Bulletin 134.

Tippett, J. M.; Kamp, P. J. J. 1993: Fission track analysis of the Late Cenozoic vertical kinematics of continental Pacific crust, South Island, New Zealand. Journal of Geophysical Research 98: 16119-16148.

White, R. J.; Green, P. F. 1986: Tectonic development of the Alpine fault zone, New Zealand: a fission track study. Geology 14: 124- 127 . 